\title{
Methylotrophs and Methylotroph Populations for Chloromethane Degradation
}

\author{
Françoise Bringel ${ }^{1 *}$, Ludovic Besaury², Pierre Amato ${ }^{3}$, Eileen Kröber ${ }^{4}$, \\ Steffen Kolb ${ }^{4}$, Frank Keppler ${ }^{5,6}$, Stéphane Vuilleumier ${ }^{1}$ and \\ Thierry Nadalig ${ }^{1}$
}

\footnotetext{
${ }^{1}$ Université de Strasbourg UMR 7156 UNISTRA CNRS, Molecular Genetics, Genomics, Microbiology (GMGM), Strasbourg, France.

${ }^{2}$ Université de Reims Champagne-Ardenne, Chaire AFERE, INRA, FARE UMR A614, Reims, France.

${ }^{3}$ Université Clermont Auvergne, CNRS, SIGMA Clermont, ICCF, Clermont-Ferrand, France.

${ }^{4}$ Microbial Biogeochemistry, Research Area Landscape Functioning - Leibniz Centre for Agricultural Landscape Research - ZALF, Müncheberg, Germany.

${ }^{5}$ Institute of Earth Sciences, Heidelberg University, Heidelberg, Germany.

${ }^{6}$ Heidelberg Center for the Environment HCE, Heidelberg University, Heidelberg, Germany.

*Correspondence: francoise.bringel@unistra.fr
}

https://doi.org/10.21775/cimb.033.149

\section{Abstract}

Chloromethane is a halogenated volatile organic compound, produced in large quantities by terrestrial vegetation. After its release to the troposphere and transport to the stratosphere, its photolysis contributes to the degradation of stratospheric ozone. A better knowledge of chloromethane sources (production) and sinks (degradation) is a prerequisite to estimate its atmospheric budget in the context of global warming. The degradation of chloromethane by methylotrophic communities in terrestrial environments is a major underestimated chloromethane sink. Methylotrophs isolated from soils, marine environments and more recently from the phyllosphere have been grown under laboratory conditions using chloromethane as the sole carbon source. In addition to anaerobes that degrade chloromethane, the majority of cultivated strains were isolated in aerobiosis for their ability to use chloromethane as sole carbon and energy source. Among those, the Proteobacterium Methylobacterium (recently reclassified as Methylorubrum) harbours the only characterized 'chloromethane utilization' ( $\mathrm{cmu}$ ) pathway, so far. This pathway may not be representative of chloromethane-utilizing populations in the environment as $\mathrm{cmu}$ genes are rare in metagenomes. Recently, combined 'omics' biological approaches with chloromethane carbon and hydrogen stable isotope fractionation measurements in microcosms, indicated that microorganisms in soils and the phyllosphere (plant aerial parts) represent major sinks of chloromethane in contrast to more recently recognized microbe-inhabited environments, such as clouds. Cultivated chloromethane-degraders lacking $\mathrm{cmu}$ genes display a singular isotope fractionation signature of chloromethane. Moreover, ${ }^{13} \mathrm{CH}_{3} \mathrm{Cl}$ labelling of active methylotrophic communities by stable isotope probing in soils identify taxa that differ from those known for chloromethane degradation. These observations suggest that new biomarkers for detecting active microbial chloromethane-utilizers in the environment are needed to assess the contribution of microorganisms to the global chloromethane cycle. 


\section{Introduction}

\section{Chloromethane and stratospheric ozone depletion}

Chloromethane (methyl chloride, $\mathrm{CH}_{3} \mathrm{Cl}$ ) is the most abundant organohalogen in the Earth atmosphere. Its global production is estimated at 4-5 megatons per year, with main sources stemming from terrestrial vegetation (Keppler, 2005). Photolytic degradation of chloromethane releases a halogen radical, which catalyses the destruction of ozone. Thus, chloromethane contributes to depletion of the stratospheric ozone layer (altitude of approximately 20 to $30 \mathrm{~km}$ ), which constitutes the Earth's natural protective shield that absorbs the solar UVC and partially UVB radiation dangerous for living organisms. Until the 1990s, chloromethane was used as a refrigerant under the name Freon 40. Chloromethane has a stratospheric lifetime of about one year, much shorter than most other chlorofluorocarbons (CFCs), solvents and halons also banned by the international agreement of 1987 known as the Montreal Protocol on substances that deplete the ozone layer (see web resource section). There are still some uncertainties about chloromethane anthropogenic emissions (e.g. coal combustion, feedstock for chemical industries) (Li et al., 2017). Chloromethane is responsible alone for approximately $16 \%$ of stratospheric chlorine-catalysed ozone destruction (Carpenter et al., 2014). A detailed understanding of its sources and sinks will be essential to predict changes in atmospheric chloromethane fluxes in the context of global climate change.

\section{Chloromethane sources and sinks}

Chloromethane formation in plants and soil involves biotic and abiotic processes. Chloride ion can be alkylated during the abiotic oxidation of organic matter by an electron acceptor such as $\mathrm{Fe}$ (III) in soils and sediments (Keppler et al., 2000). Abiotic chloromethane mainly results from the conversion of plant methoxyl groups (ether- or ester-bonded methyl groups) and their reaction with chloride ion (Keppler et al., 2000; Hamilton et al., 2003; Sailaukhanuly et al., 2014). This process occurs in terrestrial ecosystems at ambient temperatures (Derendorp et al., 2012; Keppler et al., 2014), but it is much more efficient at higher temperatures such as those reached during pyrolysis and biomass burning (Hamilton et al., 2003; Keppler, 2005; McRoberts et al., 2015). Chloromethane release was also detected during thermal conversion of Martian soils by the Mars landers Viking (Biemann et al., 1976) and Curiosity (Ming et al., 2014), indicating the presence of endogenous organic matter on Mars. Chloromethane emission profiles during thermal treatment of soils sampled from other hyperarid environments hostile microbial life such as the Atacama desert were almost identical to those recorded by the Curiosity rover on Mars (Schulze-Makuch et al., 2018). Furthermore, chloromethane formation was observed from thermal conversion of extraterrestrial material such as carbonaceous meteorites (Keppler et al., 2014) and in protostellar environments (Fayolle et al., 2017). These recent observations contributed to the emergence of an 'astronomical' fundamental interest in the understanding of chloromethane's cycle in sun-like stars and on Earth.

On Earth, plants (alive or decaying) are a major biotic source of chloromethane. Chloromethane is produced by enzymatic chloride ion methylation, as shown in higher plants affiliated to the Brassicaceae family (Attieh et al., 1995; Rhew et al., 2003) and wood-degrading fungi (Harper et al., 1990). The S-adenosyl-L-methionine-dependent halide ion methyltransferase is encoded by gene HOL1 (Harmless to Ozone Layer) in Arabidopsis thaliana (Nagatoshi and Nakamura, 2009). HOL1 gene disruption correlates with decreased pathogen defence, possibly due to reduced production of methyl thiocyanate $\left(\mathrm{CH}_{3} \mathrm{SCN}\right)$ from glucosinolate-derived thiocyanate by HOL1 (Manley, 2002; Rhew et al., 2003; Nagatoshi and Nakamura, 2009). Chloromethane production is considered a byproduct of plant thiocyanate metabolism. Such methyltransferases have also been detected in other crop and seaside plants (Itoh et al., 2009) including marine algae (Wuosmaa and Hager, 1990; Ohsawa et al., 2001; Toda and Itoh, 2011).

Identified chloromethane sinks are dominated by abiotic loss processes in the atmosphere involving reaction with $\mathrm{OH}$ radicals, or via chlorine radicals in the marine atmospheric boundary layer (see Web resources). The extent 
of consumption of chloromethane under the control of biological processes, especially by microorganisms, constitutes one of the largest uncertainties regarding the global budget of chloromethane (Harper and Hamilton, 2003; Keppler, 2005).

\section{Microbial degradation: an underestimated sink in the global chloromethane budget}

The study of ecology and diversity of chloromethane and other methyl halide-degrading microorganisms remain a challenging field of environmental biology. Key microbial enzymes of (de)halogenation activity and active microorganisms in chlorine and other halogens (fluorine, bromine, iodine) cycling remain largely unknown (Weigold et al., 2016). The global impact of microorganisms on the chloromethane sink is difficult to quantify due to concomitant processes of production and degradation of chloromethane in the environment. For instance, highly fluctuating chloromethane emissions occur in fern plants as recently discussed (Jaeger et al., 2018b). Both production and degradation of chloromethane may coexist within a single organism as reported for lignin-degrading fungi. Unlike most other wood-rotting fungi, in Phanerochaete chrysosporium, Phlebia radiata, and Coriolus versicolor, chloromethane serves as an endogenous methyl donor in veratryl alcohol biosynthesis so that no chloromethane is emitted during lignin degradation and growth (Harper et al., 1990; Coulter et al., 1993). However, so far, methyl halide $\left(\mathrm{CH}_{3} \mathrm{X}\right.$; chloromethane, bromomethane and iodomethane) cycling studies focused on chloromethane degradation by bacteria rather than by fungi (Leisinger and Braus-Stromeyer, 1995; Harper, 2000; McDonald et al., 2002; Schäfer et al., 2007; Cox et al., 2012). While the possible implications of fungal populations on the chloromethane cycle remain to be assessed using 'omics' approaches, the aim of this review is primarily to discuss recent investigations of bacterial populations associated with chloromethane sinks in contrasting terrestrial environments, these populations potentially differing from the so far characterized microbes with known pathways for chloromethane degradation. This possibility raises questions about the composition, distribution, functioning and evolution of chloromethane-utilizing populations in response to highly fluctuating emissions of this volatile halogenated compound at the soil-plant-atmosphere interfaces.

\section{Assessing bacterial \\ chloromethane sinks}

Recent investigations of plant and soil samples suggest that chloromethane-degraders represent a minor fraction of microbial communities (Chaignaud et al., 2018; Jaeger et al., 2018a,b) that are estimated as $10^{7}$ cells per $\mathrm{cm}^{2}$ of leaf surface to $10^{9}$ cells per $\mathrm{g}$ of soil (Vorholt, 2012). In air, microbial concentrations range from a few tens to billions per cubic metre depending on location, altitude above ground, and time of the day and year (Amato et al., 2017a; DasSarma and DasSarma, 2018), representing a total of $10^{19}$ bacterial cells in the atmosphere (Whitman et al., 1998). Microorganisms collected from aerosols, cloud and rain waters retain metabolic activity under cloud-like conditions and are able to utilize atmospheric organic compounds such as formaldehyde and formate present at relatively high concentrations in cloud droplets $(\approx 1-100 \mu \mathrm{M})$ (Amato et al., 2007; Delort et al., 2010; Vaïtilingom et al., 2013; Šantl-Temkiv et al., 2017). While cloud-borne microbial assemblages include active facultative methylotrophs (Amato et al., 2017b), no isolate grew on chloromethane, no chloromethane consumption was observed (Fig. 8.1), and, consistently, no сmuA gene was detected using a highly sensitive capture hybridization method (see below). In contrast, viable methanotrophs (Methylosinus and Methylocystis) isolated from atmospheric samples (aerosol and rain) (Šantl-Temkiv et al., 2013) were able to use methane under cloud-like physicochemical conditions at concentrations relevant for the atmospheric environment $(\approx 1.5 \mathrm{ppm})$. We concluded that the microbiota thriving in the investigated clouds do not represent a significant sink for chloromethane, unlike soils, aerial parts of plants (phyllosphere), or marine environments (Goodwin et al., 2005; Schäfer et al., 2007; Chaignaud et al., 2018; Jaeger et al., 2018a,b). 

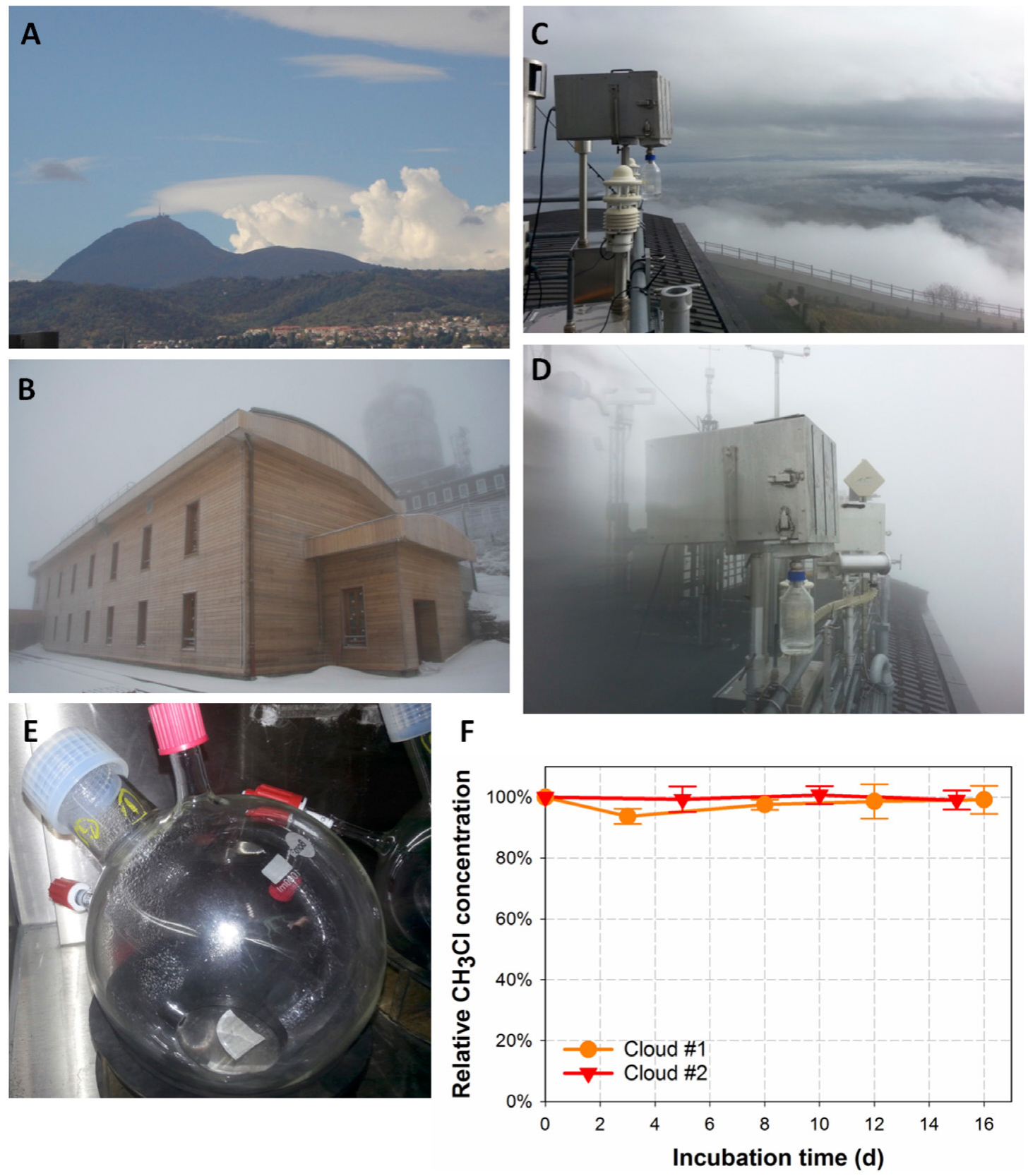

Figure 8.1 Assessing cloud water microorganisms for chloromethane degradation. Cloud water samples were collected under sterile conditions from the atmospheric station at Puy de Dôme mountain summit (1465 m above see level, France) (A) at the roof platform of a historical meteorological station (B) using cloud droplet impactors (C and D) as previously described (Amato et al., 2017b). Airtight microcosms used for testing chloromethane $(\approx 10 \mathrm{ppm})$ degradation of the collected cloud water samples $(\mathrm{E})$. Two independent cloud water samples (626 ml and $740 \mathrm{ml}$, respectively, containing $\approx 10^{6}$ cells pre-concentrated into $20 \mathrm{ml}$ ) showed no detectable temporal decrease of chloromethane under the tested conditions at $17^{\circ} \mathrm{C}(\mathrm{F})$. $M$. extorquens $\mathrm{CM} 4$ added in sterile rainwater spiked with $10 \mathrm{mM}$ of chloromethane was used as positive control (data not shown). No isolate grew on chloromethane supplied as the sole source of carbon and energy (data not shown) in enrichment cultures of cloud and rain samples, performed as previously described (Nadalig et al., 2011). 


\section{Cultivated chloromethane- degrading methylotrophs}

Methylotrophic bacteria capable of utilizing chloromethane as the only source of carbon and/or energy have been isolated (Schaefer et al., 2002; Nadalig et al., 2014) from contrasting environments such as soil, plants, freshwater and marine environments (Table 8.1). Chloromethane degraders are found among facultative aerobes, obligate anaerobes, obligate and facultative methylotrophs, and conditional utilizers of chloromethane. This diversity is encompassed by organisms possessing genomes ranging in size from very small $(1.3 \mathrm{Mb})$ to relatively large $(6.2 \mathrm{Mb}), \mathrm{G}+\mathrm{C}$ contents ranging from $38 \%$ to $68 \%$, and chloromethane utilization genes can be chromosome- or plasmidborne (Table 8.1).

Under strictly anoxic conditions, the only known pure culture that uses chloromethane as the sole energy source is the Gram-positive homoacetogenic autotrophic bacterium, Acetobacterium dehalogenans MC (Traunecker et al., 1991). In this strain, chloromethane dehalogenation releases methyl-tetrahydrofolate $\left(\mathrm{H}_{4} \mathrm{~F}\right)$ that is further metabolized to acetate (Meßmer et al., 1993, 1996). Pseudomonas aeruginosa NB1 uses chloromethane as the sole source of carbon and energy under either anoxic or aerobic conditions upon switching from nitrate to oxygen as the terminal electron acceptor (Freedman et al.,2004). Another case of anoxic chloromethane-utilization was recently reported and provides the first example of co-utilization of two chlorinated methane substrates in a mixed culture. In the absence of dichloromethane, chloromethane was not degraded as the chloromethane-degrader partner is thought to consume $\mathrm{H}_{2}$ generated by Candidatus Dichloromethanomonas elyunquensis upon dichloromethane degradation (Chen et al., 2017) (Fig. 8.2A).

Under aerobic conditions, cometabolic degradation of chloromethane was observed by nitrifying bacteria (Rasche et al., 1991) and methanotrophs (Han and Semrau, 2000). This is attributed to the activity of ammonium- or methane monooxygenase, respectively. When chloromethane is provided at low concentration in presence of another $C_{1}$ substrate, the growth of the facultative methanotroph Methylomicrobium album BG8 is enhanced (Fig. $8.2 \mathrm{C}$ ). Another case of conditional degradation of chloromethane was found for the growth of the abundant coastal Betaproteobacterium strain HTCC2181. This obligate methylotroph utilizes chloromethane for energy only when methanol is supplied as the carbon source (Halsey et al., 2012) by a yet uncharacterized methyltransferase, with possible methyl transfer from chloromethane to $\mathrm{H}_{4} \mathrm{~F}$ (Fig. 8.2B; discussed in substrate co-utilization section).

Microbial utilization of chloromethane as the sole carbon and energy source (Fig. 8.2A) was first described in Hyphomicrobium sp. strain MC1, isolated from a sewage treatment plant in Switzerland in 1986 (Hartmans et al., 1986). Strains affiliated with other taxonomic groups were subsequently recovered from soils (Aminobacter, Hyphomicrobium, Methylorubrum), marine environments (Roseovarius, Leisingera) and plants (Hyphomicrobium) (Table 8.1). Measured doubling time during aerobic growth at $30^{\circ} \mathrm{C}$ with chloromethane $(10-15 \mathrm{mM})$ ranges from $\approx 5$ hours (Hyphomicrobium strains $\mathrm{CM} 2, \mathrm{MC} 1$ and $\mathrm{AT} 2$ ) to $\approx 19$ hours (Hyphomicrobium strains AT3 and AT4) (Nadalig et al., 2011). M. extorquens strain CM4 became the reference organism of chloromethane utilization (see below).

\section{The cmu pathway for chloromethane degradation}

Biochemistry and genetics of aerobic chloromethane utilization have been elucidated in detail in strain CM4 affiliated to Methylobacterium extorquens, recently reclassified as Methylorubrum extorquens (Green and Ardley, 2018). Using random mutagenesis of strain CM4 with a miniTn5 transposon, mutants unable to grow with chloromethane were used to identify chloromethane utilization ( $\mathrm{cmu}$ ) genes (Vannelli et al., 1998, 1999) (Fig. 8.2A). The first step involves chloromethane dehalogenation with the transfer of its methyl group to the $\mathrm{C}_{1}$ carrier tetrahydrofolate $\left(\mathrm{H}_{4} \mathrm{~F}\right)$ to produce methyl- $\mathrm{H}_{4} \mathrm{~F}$, and one chloride and one proton. The fact that the primary product of chloromethane demethylation is methyl- $\mathrm{H}_{4} \mathrm{~F}$ rather than formaldehyde differs this pathway from $\mathrm{C}_{1}$ oxidation pathways, including the methanol oxidation pathway (Chistoserdova, 2011; Studer et al., 2002). Chloromethane dehalogenase consists of the corrinoid methyltransferase $\mathrm{CmuA}$ and the $\mathrm{H}_{4} \mathrm{~F}$-dependent methyltransferase $\mathrm{CmuB}$ (Studer et al., 1999, 2001). It transforms bromomethane 
Table 8.1 Chloromethane-degrading bacteria isolated from contrasting environments

\begin{tabular}{|c|c|c|c|c|}
\hline $\begin{array}{l}\text { Name (taxonomical } \\
\text { class) }\end{array}$ & Origin & $\begin{array}{l}\text { Metabolism/trophic } \\
\text { type }\end{array}$ & Genome & Comments \\
\hline $\begin{array}{l}\text { Acetobacterium } \\
\text { dehalogenans MC } \\
\text { (Clostridia) }\end{array}$ & $\begin{array}{l}\text { Activated sludge } \\
\text { (Traunecker et al., } \\
\text { 1991) }\end{array}$ & $\begin{array}{l}\text { Anaerobic } \\
\text { homoacetogenic }\end{array}$ & $n s^{a}$ & $\begin{array}{l}\text { Chloromethane } \\
\text { dehalogenation forms } \\
\text { methyl- } \mathrm{H}_{4} \mathrm{~F}(\mathrm{Me} \text { Bmer } \\
\text { et al., 1996) }\end{array}$ \\
\hline $\begin{array}{l}\text { Acetobacterium sp. } \\
\text { in mixed culture RM } \\
\text { (with Candidatus } \\
\text { Dichloromethanomonas } \\
\text { elyunquensis) }\end{array}$ & $\begin{array}{l}\text { Pristine river } \\
\text { sediment (Justicia- } \\
\text { Leon et al., 2012) }\end{array}$ & $\begin{array}{l}\text { Anaerobic } \\
\text { hydrogenotrophic } \\
\text { chloromethane- } \\
\text { degradation }\end{array}$ & ns & $\begin{array}{l}\mathrm{H}_{2} \text {-dependent } \\
\text { chloromethane } \\
\text { degradation (Chen et } \\
\text { al., 2017) }\end{array}$ \\
\hline $\begin{array}{l}\text { Aminobacter } \\
\text { ciceronei IMB1 } \\
\text { (Alphaproteobacteria) }\end{array}$ & $\begin{array}{l}\text { Fumigated } \\
\text { strawberries } \\
\text { (Hancock et al., } \\
\text { 1998) }\end{array}$ & $\begin{array}{l}\text { Aerobic facultative } \\
\text { methylotroph }\end{array}$ & ns & $c m u A^{b}$ \\
\hline $\begin{array}{l}\text { Aminobacter } \\
\text { lissarensis CC495 } \\
\text { (Alphaproteobacteria) }\end{array}$ & $\begin{array}{l}\text { Beech woodland soil } \\
\text { (Coulter et al., 1999) }\end{array}$ & $\begin{array}{l}\text { Aerobic facultative } \\
\text { methylotroph }\end{array}$ & ns & $c m u A^{b}$ \\
\hline $\begin{array}{l}\text { Celeribacter } \\
\text { indicus P73 } \\
\text { (Alphaproteobacteria) }\end{array}$ & $\begin{array}{l}\text { Deep-sea sediment } \\
\text { (Lai et al., 2014) }\end{array}$ & $\begin{array}{l}\text { Aerobic facultative } \\
\text { methylotroph } \\
\text { (genome-based) }^{\mathrm{c}}\end{array}$ & $\begin{array}{l}4.5 \mathrm{Mb} \text {, five } \\
\text { plasmids; } \mathrm{G}+\mathrm{C} \\
\text { content } 66 \% \text { (Cao } \\
\text { et al., 2015) }\end{array}$ & $\begin{array}{l}\text { Genome-based } \\
\text { detection of cmu } \\
\text { genes; } 3 \text { folD-purU } \\
\text { copies (This work) }\end{array}$ \\
\hline $\begin{array}{l}\text { Hyphomicrobium sp. } \\
\text { strains AT2, AT3, AT4 } \\
\text { (Alphaproteobacteria) }\end{array}$ & $\begin{array}{l}\text { Phyllosphere of } \\
\text { Arabidopsis thaliana } \\
\text { (Nadalig et al., 2011) }\end{array}$ & $\begin{array}{l}\text { Aerobic facultative } \\
\text { methylotroph }\end{array}$ & ns & $c m u A^{b}$ \\
\hline $\begin{array}{l}\text { Hyphomicrobium } \\
\text { sp. MC1 } \\
\text { (Alphaproteobacteria) }\end{array}$ & $\begin{array}{l}\text { Industrial sewage } \\
\text { plan (Hartmans et al., } \\
\text { 1986) }\end{array}$ & $\begin{array}{l}\text { Aerobic facultative } \\
\text { methylotroph }\end{array}$ & $\begin{array}{l}4.7 \mathrm{Mb} ; \mathrm{G}+\mathrm{C} \\
\text { content } 59 \% \\
\text { (Vuilleumier et al., } \\
\text { 2011) }\end{array}$ & $\begin{array}{l}\text { Complete } \mathrm{cmu} \\
\text { pathway }\end{array}$ \\
\hline $\begin{array}{l}\text { Hyphomicrobium } \\
\text { sp. MC2 } \\
\text { (Alphaproteobacteria) }\end{array}$ & $\begin{array}{l}\text { Soil from a } \\
\text { petrochemical } \\
\text { factory (Doronina et } \\
\text { al., 1996) }\end{array}$ & $\begin{array}{l}\text { Aerobic facultative } \\
\text { methylotroph }\end{array}$ & ns & $c m u A^{b}$ \\
\hline $\begin{array}{l}\text { Leisingera } \\
\text { methylohalidovorans } \\
\text { MB2 } \\
\text { (Alphaproteobacteria) }\end{array}$ & $\begin{array}{l}\text { Marine tide pool } \\
\text { (Schaefer et al., } \\
\text { 2002) }\end{array}$ & $\begin{array}{l}\text { Aerobic facultative } \\
\text { methylotroph }\end{array}$ & $\begin{array}{l}4.6 \mathrm{Mb} \text {, two } \\
\text { plasmids; } \mathrm{G}+\mathrm{C} \\
\text { content } 62 \% \\
\text { (Buddruhs et al., } \\
2013 \text { ) }\end{array}$ & $\begin{array}{l}\text { Uncharacterized } \\
\text { cmu-independent } \\
\text { chloromethane } \\
\text { degradation }\end{array}$ \\
\hline $\begin{array}{l}\text { Methylomicrobium } \\
\text { album BG8 } \\
\text { (Gammaproteobacteria) }\end{array}$ & $\begin{array}{l}\text { Freshwater } \\
\text { (Whittenbury et al., } \\
\text { 1970) }\end{array}$ & $\begin{array}{l}\text { Aerobic facultative } \\
\text { methanotroph, } \\
\text { obligatory } \\
\text { methylotroph }\end{array}$ & $\begin{array}{l}4.5 \mathrm{Mb} \text {, one } \\
\text { plasmid; } \mathrm{G}+\mathrm{C} \\
\text { content } 56 \% \text { (Kits } \\
\text { et al., 2013) }\end{array}$ & $\begin{array}{l}\text { Low chloromethane } \\
\text { concentrations } \\
\text { enhance growth on } \\
\text { methanol (Han and } \\
\text { Semrau, 2000). No } \\
\text { cmu gene }\end{array}$ \\
\hline $\begin{array}{l}\text { Methylorubrum }{ }^{\text {d }} \\
\text { extorquens CM4 } \\
\text { (Alphaproteobacteria) }\end{array}$ & $\begin{array}{l}\text { Soil from a } \\
\text { petrochemical } \\
\text { factory (Doronina et } \\
\text { al., 1996) }\end{array}$ & $\begin{array}{l}\text { Aerobic facultative } \\
\text { methylotroph }\end{array}$ & $\begin{array}{l}\text { 6.2 Mb, two } \\
\text { plasmids; } \mathrm{G}+\mathrm{C} \\
\text { content } 68 \% \text { (Marx } \\
\text { et al., 2012) }\end{array}$ & $\begin{array}{l}\text { Plasmid pCMU01- } \\
\text { encoded cmu (Roselli } \\
\text { et al., 2013) }\end{array}$ \\
\hline $\begin{array}{l}\text { Nocardioides sp. SAC- } \\
4 \text { (Actinobacteria) }\end{array}$ & $\begin{array}{l}\text { Topsoil (McAnulla et } \\
\text { al., 2001a) }\end{array}$ & $\begin{array}{l}\text { Aerobic facultative } \\
\text { methylotrophe }\end{array}$ & ns & \\
\hline $\begin{array}{l}\text { OM43 bacterioplankton } \\
\text { clade, strain HTCC } 2181 \\
\text { (Betaproteobacteria) }\end{array}$ & $\begin{array}{l}\text { Seawater } \\
\text { (Giovannoni et al., } \\
\text { 2008) }\end{array}$ & $\begin{array}{l}\text { Obligate } \\
\text { methylotroph }\end{array}$ & $\begin{array}{l}1.3 \mathrm{Mb} \text { (three } \\
\text { contigs); } \mathrm{G}+\mathrm{C} \\
\text { content } 38 \% \\
\text { (Giovannoni et al., } \\
2008 \text { ) }\end{array}$ & $\begin{array}{l}\text { cmu-independent } \\
\text { chloromethane use } \\
\text { as energy source if } \\
\text { methanol is the C } \\
\text { source (Halsey et al., } \\
\text { 2012) }\end{array}$ \\
\hline
\end{tabular}


Table 8.1 Continued

\begin{tabular}{|c|c|c|c|c|}
\hline $\begin{array}{l}\text { Name (taxonomical } \\
\text { class) }\end{array}$ & Origin & $\begin{array}{l}\text { Metabolism/trophic } \\
\text { type }\end{array}$ & Genome & Comments \\
\hline $\begin{array}{l}\text { Pseudomonas } \\
\text { aeruginosa NB1 } \\
\text { (Gammaproteobacteria) }\end{array}$ & $\begin{array}{l}\text { Anoxic activated } \\
\text { sludge enrichment } \\
\text { culture (Freedman et } \\
\text { al., 2004) }\end{array}$ & $\begin{array}{l}\text { Aerobic facultative } \\
\text { methylotroph }\end{array}$ & ns & $\begin{array}{l}\text { Nitrate respiration, } \\
\text { chloromethane used } \\
\text { as } C \text { and energy } \\
\text { source (Freedman et } \\
\text { al., 2004) }\end{array}$ \\
\hline $\begin{array}{l}\text { Roseovarius } \\
\text { pacificus } 81-2 \\
\text { (Alphaproteobacteria) }\end{array}$ & $\begin{array}{l}\text { Deep-sea sediment } \\
\text { (Wang et al., 2009) }\end{array}$ & $\begin{array}{l}\text { Aerobic facultative } \\
\text { methylotroph }^{c}\end{array}$ & $\begin{array}{l}4.5 \mathrm{Mb} \text { (52 contigs, } \\
\text { one plasmid); } \\
\mathrm{G}+\mathrm{C} \text { content } 62 \% \\
\text { (Wang et al., 2009) }\end{array}$ & $\begin{array}{l}\text { Genome-based } \\
\text { detection of } \mathrm{cmu} \\
\text { genes (this work) }\end{array}$ \\
\hline $\begin{array}{l}\text { Roseovarius } \\
\text { sp. strain } 217 \\
\text { (Alphaproteobacteria) }\end{array}$ & $\begin{array}{l}\text { Seawater (Schäfer et } \\
\text { al., 2005) }\end{array}$ & $\begin{array}{l}\text { Aerobic facultative } \\
\text { methylotroph }\end{array}$ & $\begin{array}{l}\text { 4.6 Mb (37 contigs); } \\
\text { G+ C content } 61 \% \\
\text { (Moore Foundation } \\
\text { project } N Z \text { - } \\
\text { AAMV00000000) }\end{array}$ & $\begin{array}{l}\text { Uncharacterized } \\
\text { cmu-independent } \\
\text { chloromethane } \\
\text { degradation pathway }\end{array}$ \\
\hline $\begin{array}{l}\text { Roseovarius sp. } \\
\text { strains 179, } 198 \\
\text { (Alphaproteobacteria) }\end{array}$ & $\begin{array}{l}\text { Seawater (Schäfer et } \\
\text { al., 2005) }\end{array}$ & $\begin{array}{l}\text { Aerobic facultative } \\
\text { methylotroph }\end{array}$ & ns & $c m u A^{\mathrm{b}}$ \\
\hline
\end{tabular}

ans, not sequenced; b gene cmuA was PCR amplified and sequenced; 'chloromethane has not been tested to

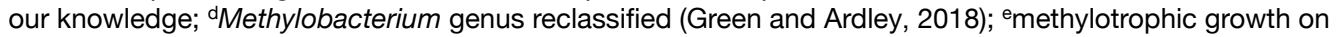
chloromethane but no other tested $\mathrm{C}_{1}$ compound (formate, methanol, methane, methylamine) (McAnulla et al., 2001a).

and iodomethane as well as chloromethane (Vannelli et al., 1998). Both proteins CmuB (Studer et al., 1999) and CmuA (Studer et al., 2001) are required for growth-supporting dehalogenation of chloromethane. CmuA acts as a bifunctional enzyme (possessing methyltransferase and the corrinoid-binding domains), and it also serves as an intermediate methyl carrier. In a second reaction, CmuB methyltransferase transfers the methyl group from $\mathrm{CmuA}$ to $\mathrm{H}_{4} \mathrm{~F}$ (Studer et al., 2001). Thus, besides $\mathrm{H}_{4} \mathrm{~F}$, chloromethane dehalogenation requires a corrinoid cofactor, which explains an absolute need for cobalt for growth with methyl halides (Studer et al., 2001). This uncharacterized corrinoid cofactor possibly differs from the chromosome-encoded cobalamin compound (Roselli et al., 2013). In M. extorquens strain CM4, all genes of the $c m u$ pathway and cob genes are present on a $380 \mathrm{~kb}$ plasmid called pCMU01. Comparison of complete genome sequences of strain CM4 with those of other M. extorquens strains unable to grow with chloromethane showed that plasmid pCMU01 harbours unique genes without homologues in the compared genomes (bluB2, btuB, cobA, cbiD), as well as 13 duplicated genes with homologues of chromosome-borne genes involved in cobalaminassociated biosynthesis and transport, or in
$\mathrm{H}_{4} \mathrm{~F}$-dependent metabolism (folC2) (Roselli et al., 2013). The clustering of genes coding for dehalogenase enzymes and for biosynthesis of associated cofactors suggests a history of coupled enzyme/ coenzyme gene acquisition related to chloromethane utilization in strain CM4.

\section{Coping with chloromethane upon methylotrophic growth}

Bacteria that grow on chloromethane need to accommodate multiple stresses such as intracellular production of protons and chloride, adjustment of metabolism towards higher demand for dehalogenase-requiring cofactors $\left(\mathrm{H}_{4} \mathrm{~F}\right.$ and cobalamin-related compounds), and the necessity to regulate their metabolism for effective chloromethane utilization (Roselli et al., 2013; Michener et al., 2016; Chaignaud et al., 2017). The limiting factors were inferred from experimental observations: (i) growth with chloromethane is slower than with methanol (Chaignaud et al., 2017); (ii) difference in growth rates under chloromethane utilization are not due to differences in chloromethane dehalogenase activity in cell-free extracts of taxonomically-related strains (Nadalig et al., 2011); and (iii) transfer of a $\mathrm{cmu}$ catabolic pathway gene cassette (plasmid pJM105) in 'naïve' 
(A)

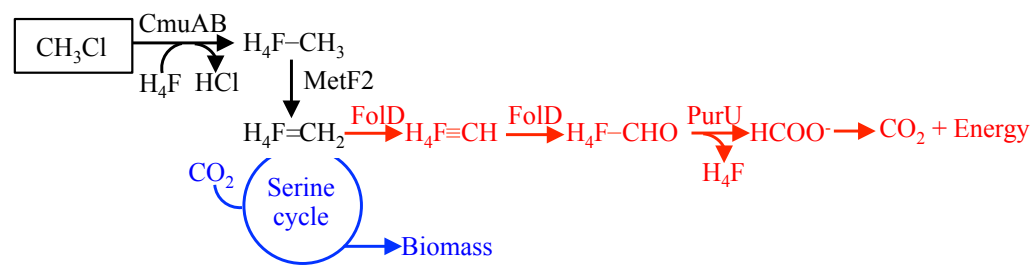

(B)

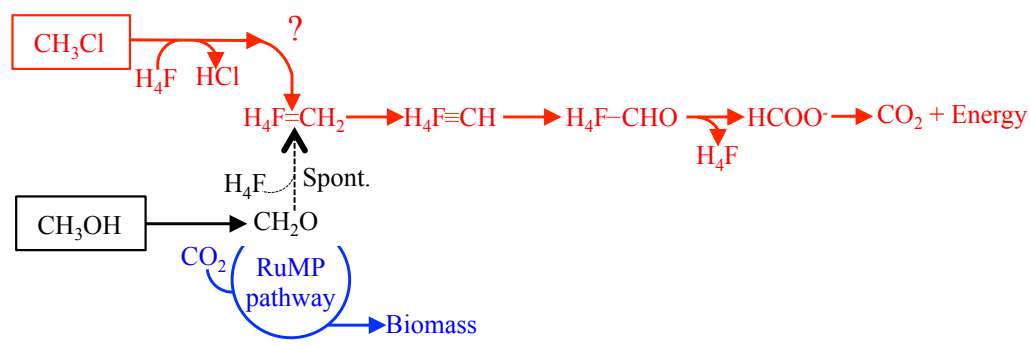

(C)

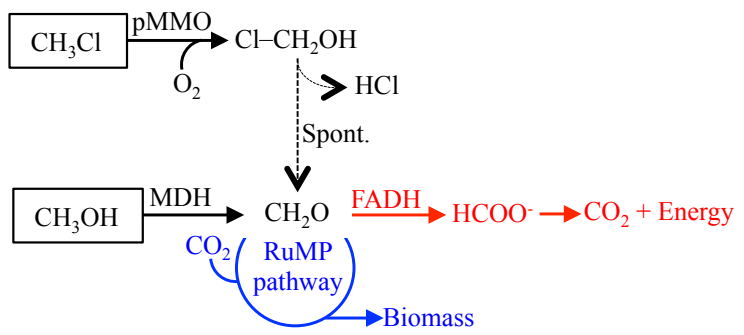

(D)

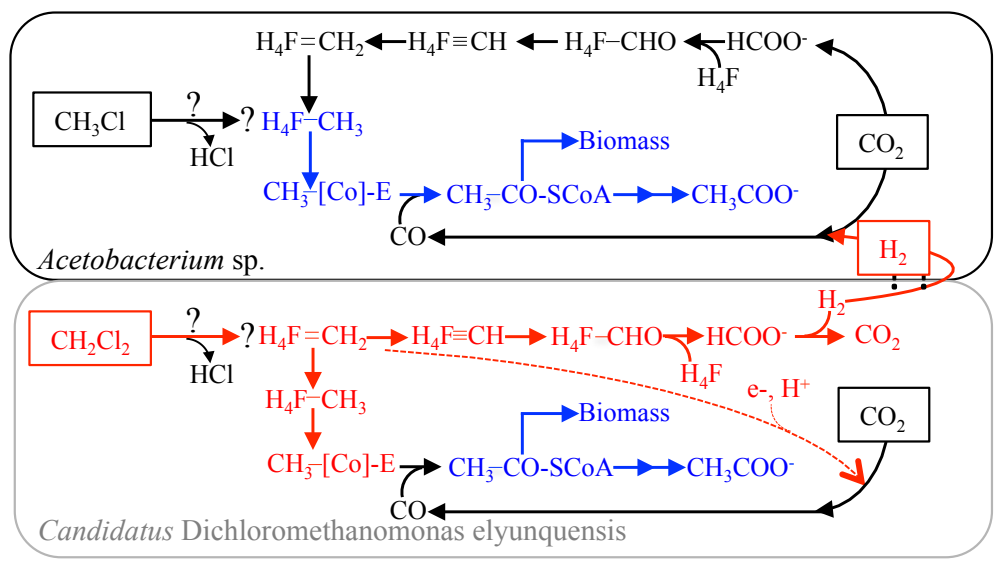

Figure 8.2 Examples of methylotrophic pathways for chloromethane dissimilation (source of energy, in red) and assimilation (source of carbon for biomass, in blue) in cultivated strains and mixed cultures. Bacteria cultivated under aerobic (A to $\mathrm{C}$ ) and anaerobic (D) conditions. Abbreviations: FADH, formaldehyde dehydrogenase; $\mathrm{H}_{4} \mathrm{~F}$, tetrahydrofolate; MDH, methanol dehydrogenase; pMMO, particulate methane monooxygenase; RuMP, ribulose monophosphate pathway. (A) The cmu pathway characterized in details in $M$. extorquens CM4 and Hyphomicrobium strains, adapted from (Vannelli et al., 1999; McAnulla et al., 2001b); (B) Bacterioplankton HTCC2181, adapted from (Giovannoni et al., 2008); (C) Methylomicrobium album BG8, adapted from (Han and Semrau, 2000); and (D) Culture RM, adapted from (Chen et al., 2017). Chloromethane and dichloromethane are each degraded by a different organism in a mutualism interaction. Chloromethane could not substitute for dichloromethane as the sole source of energy. It remains unknown how chloromethane enters the $\mathrm{C}_{1}$ cycle of the chloromethane-degrading homoacetogen strain performing $\mathrm{H}_{2} / \mathrm{CO}_{2}$ reductive acetogenesis (Kleindienst et al., 2017). For Candidatus Dichloromethanomonas elyunquensis, dichloromethane is a source of energy. No dichloromethane degradation occurs in medium without $\mathrm{CO}_{2}$ (bicarbonate) supplementation (Kleindienst et al., 2017). Enzymes involved in dichloromethane degradation and $\mathrm{CO}_{2}$ assimilation have not been characterized. 
Methylorubrum strains conferred poor growth ability on chloromethane supplied as the sole energy and carbon source (Michener et al., 2016). Among potential limiting factors, intracellular release of protons and chloride ions is likely, since dehalogenation of chloromethane, as of dichloromethane, initiates growth-supporting degradation. Nonetheless, each of these chlorinated methanes has specific adaptive responses for chloride export. For example, in Methylorubrum, the chromosomeencoded proton/chloride antiporter ClcA had a significant fitness impact for growth with dichloromethane but not with chloromethane (Michener et al., 2014a, 2016). Adaptive responses to growth with chloromethane compared with growth with methanol were detected using complementary approaches of random mutagenesis (Vannelli et al., 1999), genome sequencing (Marx et al., 2012), comparative genomics, proteomics and transcriptomics (Roselli et al., 2013; Chaignaud et al., 2017), and experimental evolution (Michener et al., 2016). A summary of the global response to growth with chloromethane in $M$. extorquens strain CM4 is proposed in Fig. 8.3.

According to this model, the adaptive response to chloromethane is complex and includes general oxidative stress response functions (Fig. 8.3) such as molecular chaperones, DNA repair and reactive oxygen species (ROS) removal functions, as well as a dehalogenation-specific response to intracellular hydrochloric acid production (membrane-bound proton translocating pyrophosphatase HppA and a putative chloride/proton antiporter $\mathrm{ClcA} 2$ encoded by plasmid pCMU01). The pnt gene cluster encoding a $\mathrm{NADH} / \mathrm{NADPH}$ transhydrogenase with cross-membrane proton translocation activity, most likely plays a role in maintaining both the intracellular pools of $\mathrm{NAD}^{+}$and $\mathrm{NADP}^{+}$, and the internal cellular $\mathrm{pH}$ with the efflux of protons during chloromethane dehalogenation. Higher expression of genes (enzymes and transporters) for biosynthesis of methyltransferase cofactors were detected, especially bluB2 (sharing $38 \%$ amino acid identity with the chromosomal-encoded bluB gene). BluB

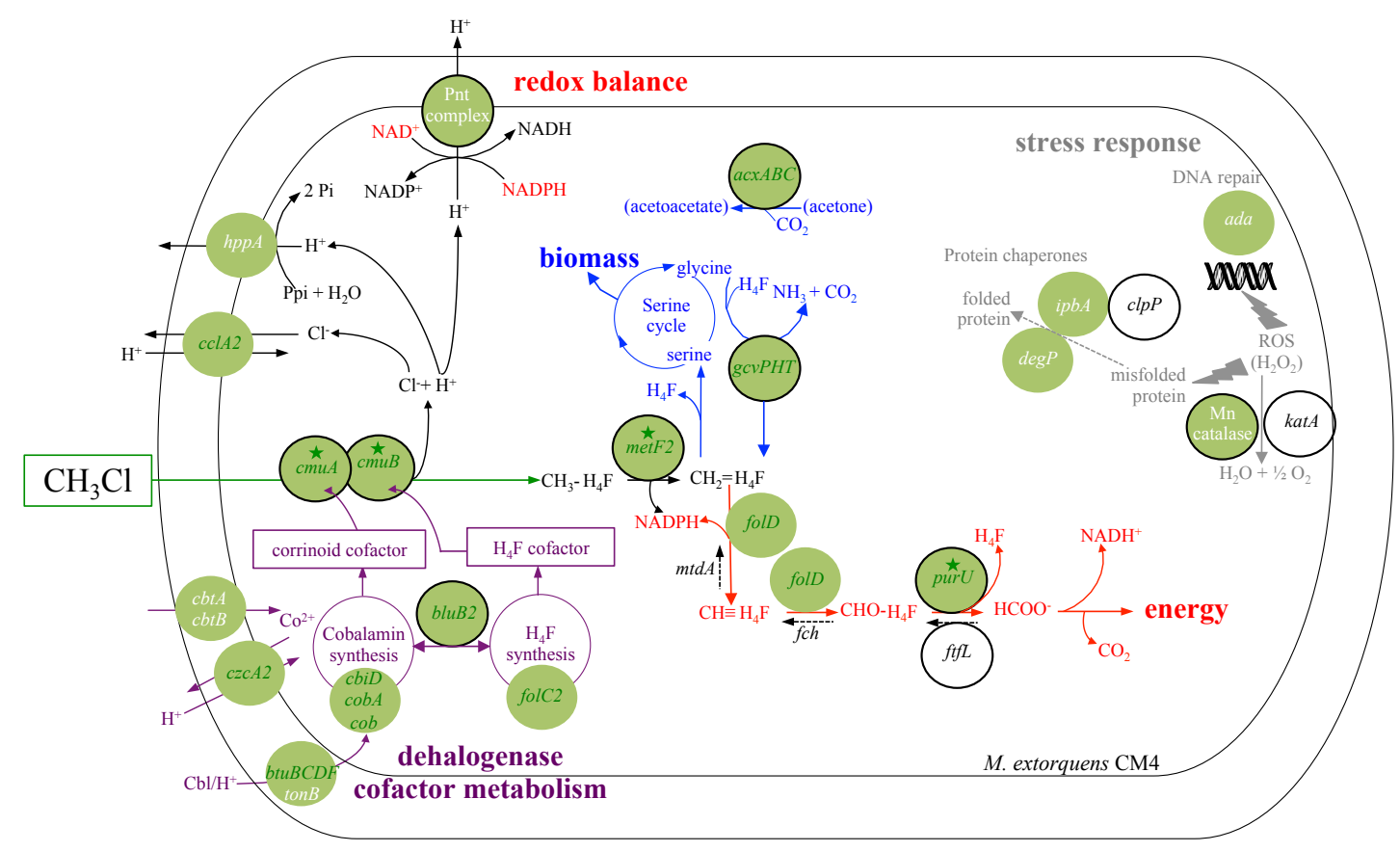

Figure 8.3 Coping with chloromethane upon methylotrophic growth. In M. extorquens CM4, the cmu pathwayencoding genes and associated genes are plasmid pCMU01-borne (gene names in green). In cultures grown on chloromethane compared with methanol, more abundant RNAs (green bullets) (Chaignaud et al., 2017) and proteins (black-circled bullets) (Roselli et al., 2013) were found. Essential genes in chloromethane assimilation or dechlorination are marked with a star (Vannelli et al., 1999; Michener et al., 2016). For the putative role of the acetone carboxylase components encoded by the plasmid-borne acxABC gene cluster chloromethane assimilation, refer to Roselli et al. (2013). 
catalyses both the production of a lower ligand of cobalamin (5,6-dimethylbenzimidazole) and of a $\mathrm{H}_{4} \mathrm{~F}$ precursor (erythrose $4 \mathrm{P}$ ), thus linking together the biosynthesis of the two cofactors of chloromethane dehalogenation (Roselli et al., 2013). In conclusion, the ability to utilize chloromethane likely involves adaptation to oxidative stress, production of reducing equivalents, conversion of $\mathrm{H}_{4}$ F-bound $\mathrm{C}_{1}$ units, and central metabolism. The adaptive response to growth with chloromethane has little overlap with other toxic halogenated compounds (Roselli et al., 2013; Michener et al., 2014b, 2016; Chaignaud et al., 2017), and possibly with chloromethane degradation by $\mathrm{cmu}$-independent pathways.

\section{Probing the diversity of \\ chloromethane-degrading \\ bacteria by comparative genomics and isotopic fractionation}

The strategy of combining stable isotope approaches (Compound-Specific Isotope
Analysis; CSIA) with comparative genomics helps to explore the diversity of microbial degradation of chloromethane (Nadalig et al., 2014). CSIA is a chemical method to determine the ratio of isotopes of different elements (e.g. C, N, H, O, Cl) in environmental samples (Nijenhuis and Richnow, 2016). This ratio can change during the course of microbial degradation. For example, carbon large fractionation shifts $\left(\delta{ }^{13} \mathrm{C}\right.$ from an initial value of $-60 \%$ o to $-30 \%$ ) were observed when $90 \%$ of the chloromethane was degraded by high-cell-density suspensions of methylotrophic bacteria (Miller et al., 2001). Combined measurements of carbon and hydrogen isotope fractionation of the remaining untransformed chloromethane provide further evidence of biotic degradation and clues about the metabolic pathway and enzymes involved (Nadalig et al., 2013) (Table 8.2). When genomes of experimentally validated chloromethane-degrading methylotrophs were searched for the presence of $c m u A$, two groups of bacteria were detected: (i) $M$. extorquens CM4 and Hyphomicrobium sp. MC1 isolated from soils share the $\mathrm{cmu}$ pathway genes; (ii) Leisingera methylohalidovorans MB2 and Roseovarius

Table 8.2 Degradation of chloromethane and its isotopic enrichment factor for carbon $\left(\varepsilon_{\mathrm{C}}\right)$ and hydrogen $\left(\varepsilon_{H}\right)$ of pure cultures and environmental samples

\begin{tabular}{|c|c|c|c|c|}
\hline & \multicolumn{4}{|c|}{$\begin{array}{l}\text { Stable isotope enrichment factor for chloromethane upon bacterial } \\
\text { degradation }^{\mathrm{a}}\end{array}$} \\
\hline & Test condition & $\varepsilon_{\mathrm{C}}(\%)$ & $\varepsilon_{H}(\% \circ)$ & Reference \\
\hline \multicolumn{5}{|l|}{ Pure bacterial cultures (cmu pathway) } \\
\hline Aminobacter ciceronei IMB1 & Resting cells, $26^{\circ} \mathrm{C}$ & $-47 \pm 4$ & $\mathrm{Nd}^{\mathrm{b}}$ & Miller et al. (2001) \\
\hline Aminobacter lissarensis CC495 & Resting cells, $26^{\circ} \mathrm{C}$ & $-42 \pm 2$ & $\mathrm{Nd}$ & Miller et al. (2001) \\
\hline \multirow[t]{2}{*}{ Methylorubrum extorquens CM4 } & Dividing cells, $30^{\circ} \mathrm{C}$ & -42 & -39 & Nadalig et al. (2014) \\
\hline & Resting cells, $30^{\circ} \mathrm{C}$ & $-41 \pm 5$ & $-29 \pm 6$ & Nadalig et al. (2013) \\
\hline \multirow[t]{2}{*}{ Hyphomicrobium sp. MC1 } & Dividing cells, $30^{\circ} \mathrm{C}$ & -54 & -51 & Nadalig et al. (2014) \\
\hline & Resting cells, $30^{\circ} \mathrm{C}$ & $-38 \pm 3$ & $-27 \pm 10$ & Nadalig et al. (2013) \\
\hline \multicolumn{5}{|c|}{ Pure bacterial cultures (cmu-independent pathway) } \\
\hline \multirow[t]{2}{*}{ Leisingera methylohalidovorans MB2 } & Dividing cells, $30^{\circ} \mathrm{C}$ & -76 & 0 & Nadalig et al. (2014) \\
\hline & Resting cells, $26^{\circ} \mathrm{C}$ & $-44 \pm 4$ & $\mathrm{Nd}$ & Miller et al. (2001) \\
\hline \multicolumn{5}{|l|}{ Environmental samples } \\
\hline Phyllosphere (fern: Cyathea cooperi) & Microcosm, $20-30^{\circ} \mathrm{C}$ & $-43 \pm 12$ & $-8 \pm 19$ & Jaeger et al. (2018b) \\
\hline $\begin{array}{l}\text { Soils (agricultural, grassland, forest } \\
\text { soils) }\end{array}$ & Microcosm, $20-30^{\circ} \mathrm{C}$ & -38 to $-11 \pm 3$ & $-50 \pm 19$ & Jaeger et al. (2018a) \\
\hline
\end{tabular}

alncreased carbon isotope fractionation compared with hydrogen isotope fractionation most likely results from the primary isotope effect in cleavage of the carbon-halogen bound during chloromethane dehalogenation, as previously suggested (Elsner et al., 2005); b Nd, not determined. 
sp. 217 isolated from marine environments harbour no $\mathrm{cmu}$ genes and degrade chloromethane by a yet uncharacterized mechanism (Table 8.1). Cultures of L. methylohalidovorans MB2 displayed clear differences of both carbon and hydrogen isotope signatures upon chloromethane dehalogenation compared with $\mathrm{cmu}$-containing strain cultures of Aminobacter, Hyphomicrobium and Methylorubrum (Nadalig et al., 2014).

The $c m u$ gene organization is unique in strain CM4 (Roselli et al., 2013), where the genes are plasmid-borne and located in two distant regions (Vannelli et al., 1998). In other strains, when detected by comparative genomics and targeted PCR amplifications, cmu genes (Fig. 8.4) were conserved on a single chromosomal cluster (McAnulla et al., 2001b; Nadalig et al., 2014). In particular, a trio of adjacent genes $(c m u B C A)$ is conserved in genomes of aerobic chloromethane-degraders isolated from soils and plants, genomes of Alphaproteobacteria isolated from deep-sea (Celeribacter indicus P73 and Roseovarius pacificus 81-2), as well as of obligate anaerobes (Desulfobacula sp. TS; Desulfomonile tiedjei DSM 6799, Desulfurispora thermophila DSM 16022, Desulfotomaculum alcoholivorax DSM 16058, Thermincola potens JR and Thermosediminibacter oceani DSM 16646). These anaerobic strains harbour $\mathrm{cmuA}$ homologues closely related to each other (identities at the protein level between 84-93\%) (Nadalig et al., 2014) but none of these strains has yet been reported to degrade chloromethane. The overall conserved сти BCA trio suggests a functional link between the encoded $\mathrm{CmuA}, \mathrm{CmuB}$ and $\mathrm{CmuC}$. While $\mathrm{CmuA}$ and $\mathrm{CmuB}$ are two methyltransferases essential for chloromethane dehalogenation (Studer et al., 2001), the function of $\mathrm{CmuC}$ remains uncharacterized. CmuC, a putative third methyltransferase-like protein most similar to MtaA (corrinoid:coenzyme M methyltransferase), is dispensable for dehalogenation but needed for chloromethane assimilation (Vannelli et al., 1999). Mobile genetic elements (black arrows in Fig. 8.4) in the vicinity of conserved cmu clusters potentially suggest their acquisition by horizontal gene transfer. Duplicated $\mathrm{cmu}$ genes found in strain CM4 (two homologous $\mathrm{cmuC}$ copies adjacent to either $c m u B$ or $c m u A$ ) and in D. tiedjei DSM 6799 (a cmuAB copy in addition to the conserved $c m u B C A$ ) suggest specific strain adaptation. An 'orphan' $c m u A$-like gene (encoding for a protein sharing $43 \%$ amino acid identity with M. extorquens CM4 CmuA) with no other detected genes of the $\mathrm{cmu}$ pathway in its genome, raises the question of whether the marine Gammaproteobacterium Vibrio orientalis CIP 102891 in able to degrade chloromethane. No chloromethane degradation was observed for $V$. orientalis CIP 102891 resting cells (Fig. 8.5) or by actively growing cell cultures supplied with chloromethane in addition to another carbon source (data not shown). This suggests that the $V$. orientalis CmuA-like homolog might play a yet unknown function, possibly different from chloromethane dehalogenation.

\section{Methylotrophic populations of the chloromethane sink}

\section{Chloromethane-degrading populations reduce chloromethane emissions to the atmosphere}

In contrast to live soils, sterilized soils or plants do not degrade chloromethane (Chaignaud et al., 2017; Jaeger et al., 2018a,b) suggesting a microbial sink of chloromethane. Compared to chloromethane degrading methylotrophs (Table 8.2), the carbon isotope enrichment factor $\left(\varepsilon_{\mathrm{C}}\right)$ of remaining chloromethane was similar for fern leaves (mean of $-43 \pm 12 \%$ ) and lower for soils (ranging from -38 to $11 \pm 3 \%$ in agricultural, grassland and forest soils, respectively). Stable isotope hydrogen fractionation $\left(\varepsilon_{\mathrm{H}}\right)$ observed during degradation experiments with fern leaves $(-8 \pm 19 \%$ ) , and soils $(-50 \pm 19 \%$ ) was similar to reported $\varepsilon_{\mathrm{H}}$ for chloromethane-degrading bacterial strains (Table 8.2). No change in stable isotope fractionation signature was observed when the investigated environmental samples were sterilized, suggesting a biotic microbially driven process (Chaignaud et al., 2017; Jaeger et al., 2018a,b). This hypothesis is in agreement with the recent finding that the occurrence and the diversity of bacterial chloromethane degradation ( $c m u$ gene expression) is correlated with differential expression of the plant gene HOL1 involved in the production of chloromethane (Farhan Ul Haque et al., 2017). Thus, a relation was established between chloromethane production by plants and relative abundance of leave-associated chloromethane-degrading bacteria. This suggests that chloromethane-degrading bacteria co-determine the extent of chloromethane 


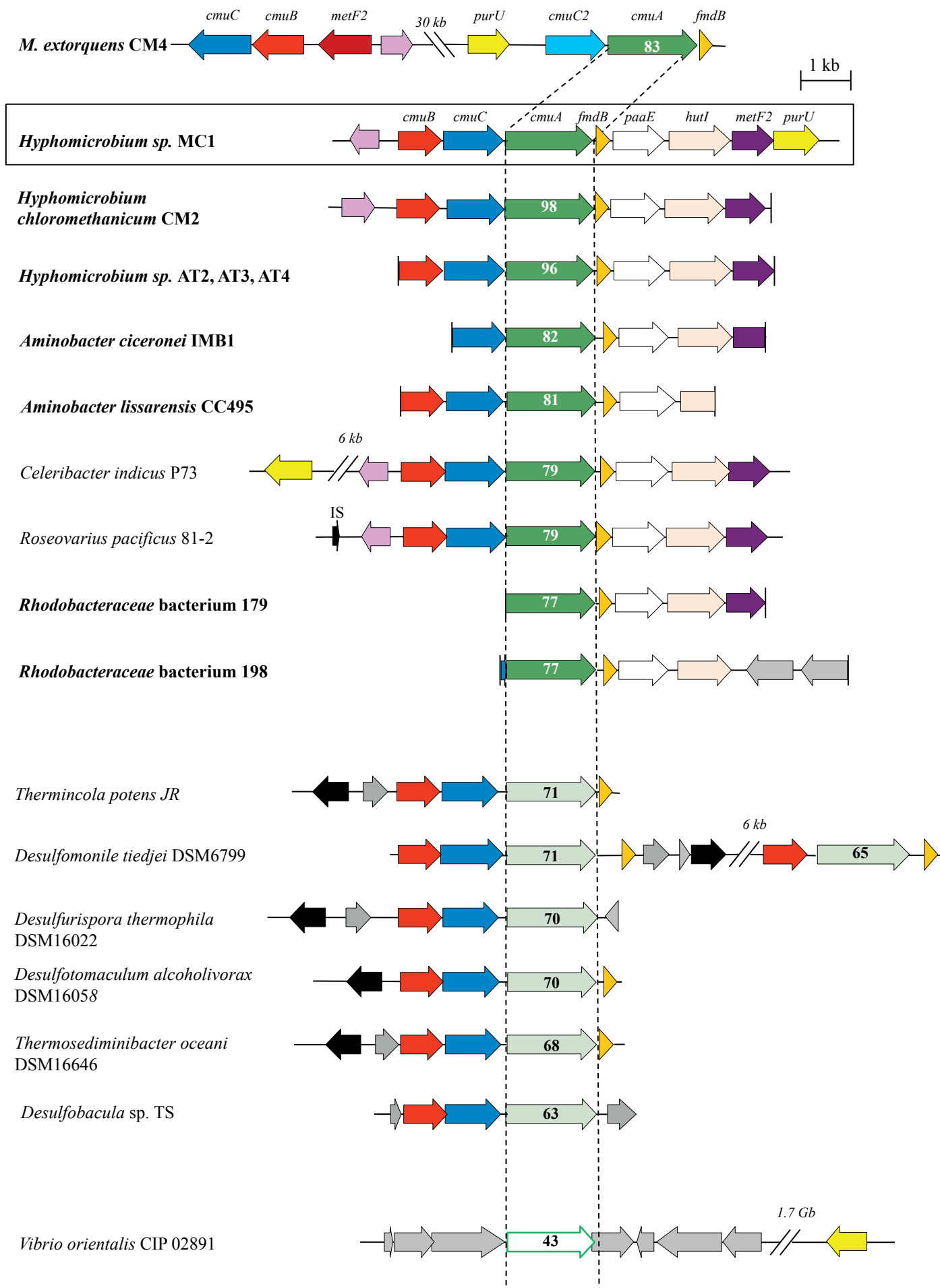

Figure 8.4 Organisation of $\mathrm{cmu}$ genes in bacteria. Names of experimentally validated chloromethane-degrading bacteria are written in bold. Arrows represent protein-coding genes, and annotations above arrows indicate gene names. Homologous genes are given with identical colour except for arrows in black, pink and grey, which indicate mobile elements, transcriptional regulators, and genes not involved in chloromethane degradation, respectively. The percentage of amino acid sequence identity with the reference Hyphomicrobium sp. MC1 CmuA protein is indicated. Gene clusters are drawn to scale. 


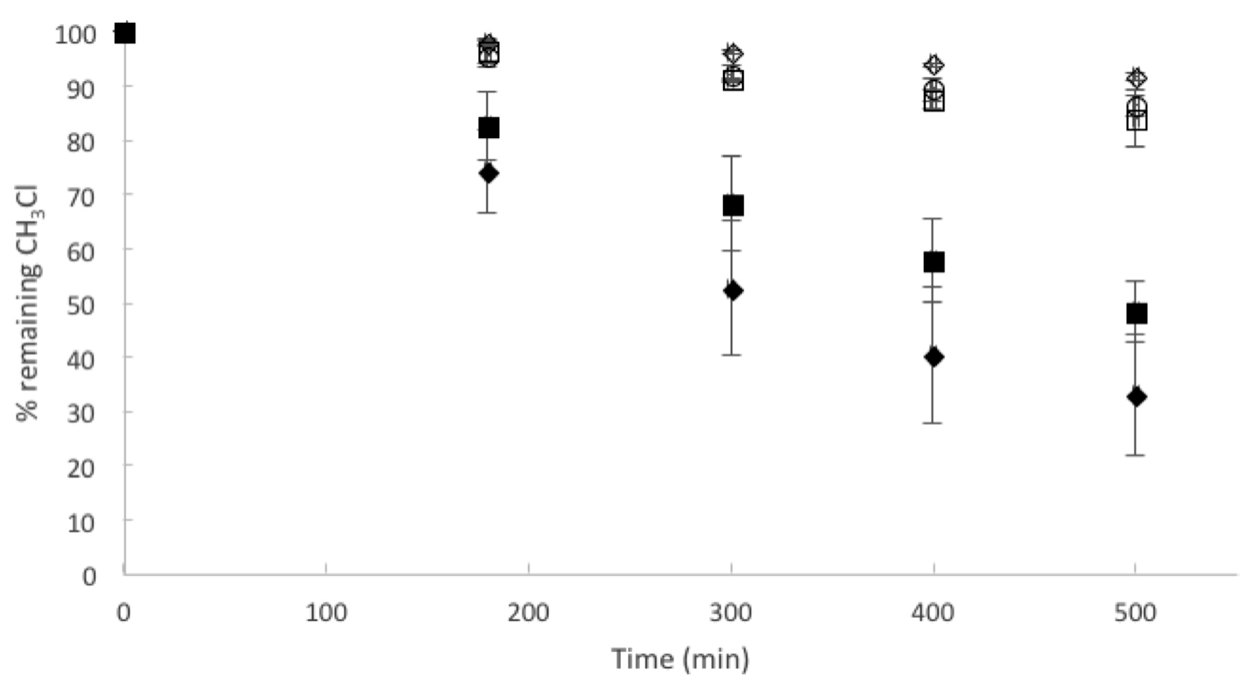

Figure 8.5 Assessing the ability of Vibrio orientalis CIP 102891 to degrade chloromethane. Triplicates of resting cells were exposed to chloromethane in gastight flasks at room temperature. The remaining chloromethane was quantified by gas chromatography (GC-FID) at different time points. Cell suspensions of $V$. orientalis CIP 102891 (empty square) were harvested from exponential-grown phase as described for $L$. methylohalidovorans MB2 saline cultures (Nadalig et al., 2014). For V. orientalis CIP 102891, the amount of chloromethane remaining was similar to that of the negative controls without cells (empty circle, saline phosphate buffer; empty diamond, phosphate buffer) but significantly different from the positive degraders $M$. extorquens CM4 in (black diamond) and L. methylohalidovorans MB2 (black square).

emissions by plants to the atmosphere, and that methylotrophic microorganisms are involved in the terrestrial chloromethane sink.

\section{Rare occurrence of $c m u A$ in the environment}

Of the genes of the $c m u$ pathway, the $c m u A$ gene is the most conserved (Farhan Ul Haque et al., 2017; Nadalig et al., 2011). Thus, стиA has been used to study the diversity of methyl halide-degrading organisms in the environment (Miller et al., 2004; Schäfer et al., 2005; Nadalig et al., 2011; Cox et al., 2012; Chaignaud et al., 2018). With increasing numbers of $c m u A$ sequences in databases, oligonucleotide primers have been modified for more efficient PCR amplification and improved detection of cmuA (see details in Chaignaud et al., 2018, supplemental material). No PCR products were retrieved from environmental DNA prior to enrichment steps of forest soil (Chaignaud et al., 2018) and plant leaves (Jaeger et al., 2018b). When amplified, a low diversity of $c m u A$ sequences was found in samples of soils, plant leaves and large volumes of oceanic and coastal waters (Cox et al., 2012; Farhan Ul Haque et al., 2017; Chaignaud et al., 2018). This suggested that $с m u A$-harbouring bacteria might represent a small component of the investigated environmental microbiota.

Recently, an extremely sensitive molecular tool for $c m u A$ detection by 'targeted gene capture' was developed (Gasc et al., 2016; Ribière et al., 2016). Its detection limit of $0.00006 \%$ makes it particularly adapted to investigate rare genes and biological functions in the environment (Gasc and Peyret, 2018). It consists of utilizing metal beads for recovering the sequences of interest within a community (or within nucleic acid extracts) by hybridization. The beads are coated with biotinylated RNA sequences of $\approx 80 \mathrm{bp}$, complementary to the targeted gene sequence and potential orthologs. Using KASpOD software (Parisot et al., 2016), such 80-mer sequences have been successfully used to design specific probes based on large sequence datasets to reveal microbial diversity missed using current profiling methods. Based on known стиA gene sequences, gene capture method was attempted in different environments [e.g. soil (Jaeger et al., 2018a), plant leaves (Jaeger et al., 2018b) and cloud microbial communities (L. Besaury, P. Amato, P. Peyret, C. Gasc, unpublished data)] with no success. When homologous sequences were searched in metagenomic databases in a wider range of 
Table 8.3 Occurrence of $c m u A$ sequences in metagenomes available from public databases

\begin{tabular}{|c|c|c|c|c|}
\hline Database & Environment & $\begin{array}{l}\text { Metagenome } \\
\text { numbers }\end{array}$ & Total size $(\mathrm{Mb})^{\mathrm{a}}$ & $c m u A$ hit $^{\mathrm{b}}$ \\
\hline \multirow[t]{40}{*}{ IMG } & Engineered & 2332 & 254,327 & \\
\hline & Bioreactor & 108 & 35,565 & 0 \\
\hline & Bioremediation & 68 & 12,879 & 0 \\
\hline & Biotransformation & 24 & 5411 & 0 \\
\hline & Build environment & 1231 & 31,275 & 0 \\
\hline & Food production & 3 & 6,600 & 0 \\
\hline & Lab enrichment & 218 & 11,002 & 0 \\
\hline & Lab synthesis & 4 & 401 & 0 \\
\hline & Modelled & 65 & 2804 & 0 \\
\hline & Solid waste & 69 & 22,575 & 0 \\
\hline & Wastewater & 542 & 132,349 & 0 \\
\hline & Aquatic & 9322 & $1,968,340$ & \\
\hline & Freshwater & 3912 & 755,498 & 0 \\
\hline & Marine & 3034 & $1,049,257$ & 1 (wetland) \\
\hline & Non-marine saline and alkaline & 702 & 86,625 & 0 \\
\hline & Sediment & 271 & 34,754 & 0 \\
\hline & Thermal spring & 1403 & 42,206 & 0 \\
\hline & Terrestrial & 2915 & $1,508,938$ & \\
\hline & Deep subsurface & 183 & 13,202 & 0 \\
\hline & Geologic & 4 & 170 & 0 \\
\hline & Oil reservoir & 3 & 283 & 0 \\
\hline & Peat & 56 & 10,558 & 0 \\
\hline & Plant litter & 47 & 2663 & 0 \\
\hline & Rock-dwelling & 8 & 3220 & 0 \\
\hline & Soil & 2609 & $1,481,714$ & 0 \\
\hline & Volcanic & 5 & 26 & 0 \\
\hline & Host-associated & 4106 & 876,365 & \\
\hline & Algae & 64 & 44,092 & 0 \\
\hline & Animal & 25 & 6426 & 0 \\
\hline & Annelida & 91 & 43,120 & 0 \\
\hline & Arthropoda & 147 & 73,213 & 0 \\
\hline & Birds & 18 & 5505 & 0 \\
\hline & Cnidaria & 36 & 723 & 0 \\
\hline & Fish & 4 & 489 & 0 \\
\hline & Fungi & 102 & 19,978 & 0 \\
\hline & Human & 2489 & 139,540 & 0 \\
\hline & Insecta & 34 & 3153 & 0 \\
\hline & Invertebrate & 15 & 8056 & 0 \\
\hline & Mammal & 267 & 104,135 & 0 \\
\hline & Microbial & 24 & 2132 & 0 \\
\hline
\end{tabular}


Table 8.3 Continued

\begin{tabular}{lllll}
\hline Database & Environment & $\begin{array}{l}\text { Metagenome } \\
\text { numbers }\end{array}$ & Total size (Mb) & cmuA hit ${ }^{\mathrm{b}}$ \\
\hline \multirow{2}{*}{ Mollusca } & 11 & 3247 & 0 \\
& Plants & 761 & 581,931 & $\begin{array}{l}3 \text { (Arabidopsis } \\
\text { thaliana) }\end{array}$ \\
& Porifera & 10 & 1642 & 0 \\
& Tunicates & 8 & 3377 & 0 \\
$\mathrm{NCBI}$ & Diverse & Metagenome BLAST database & \\
& Marine & & 81,542 & 7 (sediment) \\
& Freshwater, hydrothermal vent, human gut & & 94,265 & 0 \\
\hline
\end{tabular}

aTotal of 4,783,777 Mb publicly available in May 2018; bBlast searches were performed using a cmuA consensus template from 122 nucleic acid sequences downloaded from GenBank. Hits displaying an E-value lower than 10-5 were kept, and the corresponding proteins aligned with characterized CmuA sequences to only retain members closely related to one of three clades shown in Figure 8.6B.

environments (Table 8.3 ), only $11 \mathrm{cmuA}$ sequences were retrieved, of which three originated from the rhizosphere of the plant $A$. thaliana, and the others from marine environments (Table 8.3). Basing on these results, $c m u A$ is estimated to represent around one DNA sequence out of 3 billion, and can be considered as a rare gene (Kislyuk et al., 2011). It may be necessary for future sampling campaigns to assess if environmental niche partitioning of microbial minorities consuming chloromethane is found as for methane (Bodelier et al., 2013).

Using Blast searches, стиA DNA sequences were retrieved from environmental metagenomes, translated to proteins and aligned to reference 'sensu stricto' proteins of functionally characterized CmuA proteins of Alphaproteobacteria cultivated under aerobic conditions, to uncharacterized proteins of the clade called 'CmuA-anaerobe' found in strict anaerobes and of ' $\mathrm{CmuA}$-like' proteins found in bacteria lacking $\mathrm{cmuBC}$ (as defined in Fig. 8.6). Of the 11 metagenomic cmuA sequences, one was closely related to the 'sensu stricto CmuA' clade, one to the 'CmuA-anaerobe', and the remaining belonged to the most-distant CmuA-like clade. Remarkably, chloromethane dehalogenation by 'sensu stricto CmuA' does not require aerobic conditions and is even sensitive to oxygen (Studer et al., 2001). Thus, anaerobic bacteria with $\mathrm{cmu}$ genes may be able to use chloromethane as a source of carbon and energy, as previously discussed (Nadalig et al., 2014). Nonetheless, the ability to degrade methyl halides under environmental conditions remains to be confirmed for bacterial populations coding for 'CmuA-anaerobe' and CmuA-like proteins.

\section{Substrate co-utilization as a strategy to sustain growth and resilience of chloromethane-utilizing methylotrophic populations}

In the troposphere, chloromethane is a trace gas with a global mean concentration of $\approx 500$ to 600 parts per trillion by volume (pptv). In environments with low nutrient levels, methylotroph populations growing on different $\mathrm{C}_{1}$ substrates (Neufeld et al., 2008; Gifford et al., 2016) would benefit from simultaneous utilization of several $\mathrm{C}_{1}$ compounds as a strategy to enhance their growth. In coastal ecosystems, methanol is released during phytoplankton blooms (Heikes et al., 2002). When methanol is present in seawater, the methanol-assimilating methylotroph HTCC 2181 uses chloromethane as source of energy (Halsey et al., 2012). Its genome, one of the smallest known for bacteria, lacks the tetrahydromethanopterin $\left(\mathrm{H}_{4} \mathrm{MPT}\right) \mathrm{C}_{1}$ transfer module, so $\mathrm{C}_{1}$ transfer can only rely on $\mathrm{H}_{4} \mathrm{~F}$ (Giovannoni et al., 2008). Strain HTCC 2181 may have evolved by reducing its $\mathrm{C}_{1}$ abilities (loss of the genes for the $\mathrm{C}_{1}$ carrier, $\mathrm{H}_{4} \mathrm{MPT}$ synthesis) and thus reducing its metabolic versatility in favour of specialization on carbon compounds at low amounts (Giovannoni et al., 2008).

To our knowledge, no data are available on chloromethane concentration in upper soil of terrestrial 

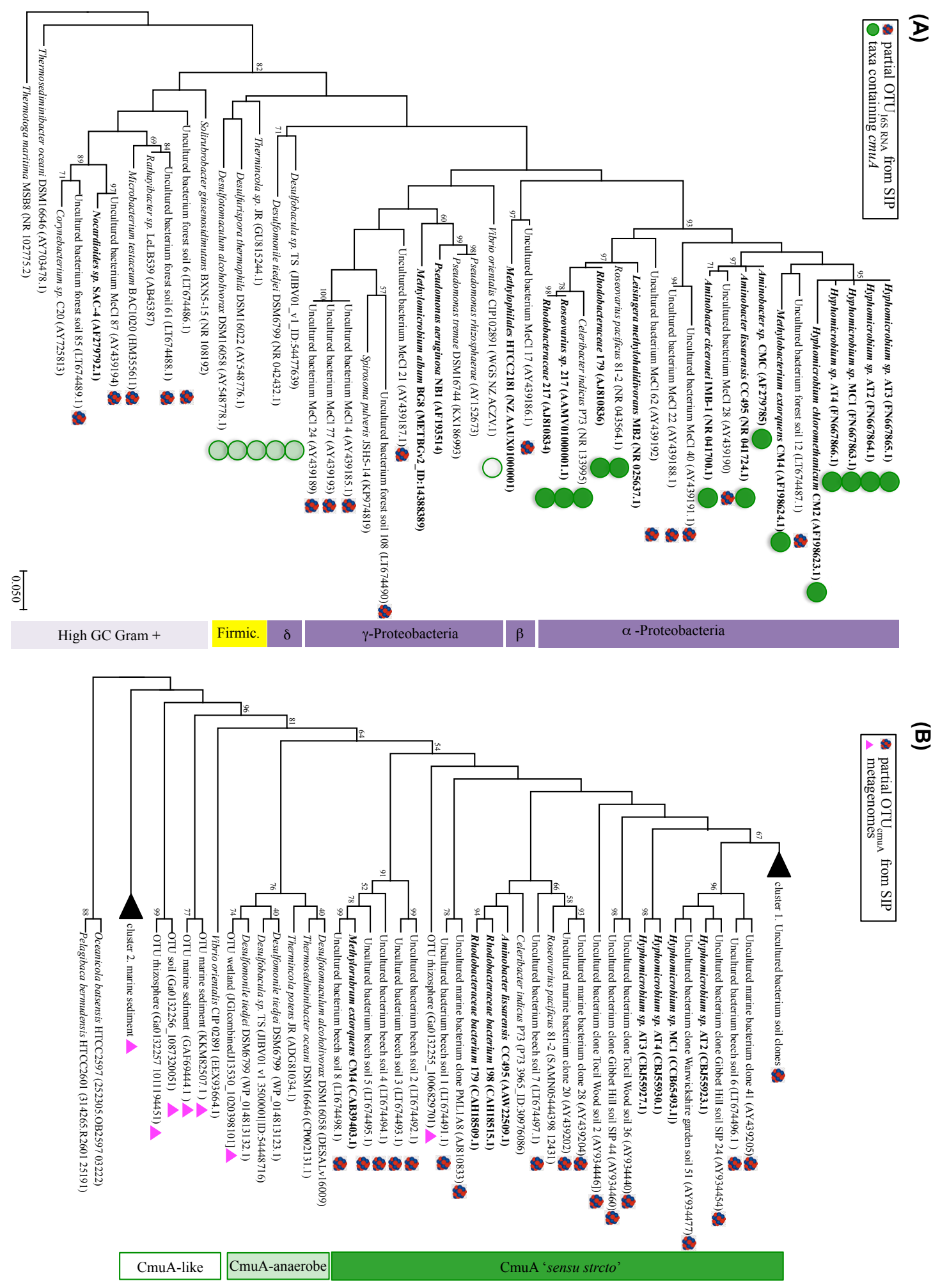
Figure 8.6 (see p.164) Phylogenetic trees of partial 16S rRNA and partial protein CmuA sequences associated with chloromethane-degradation of cultivated strains and environmental samples. The evolutionary history was inferred by using the Maximum Likelihood method based on the JTT matrix-based model (Jones et al., 1992). Bootstrap values were calculated from 1000 replicates, $\%$ values $\geq 50$ are presented. Analyses were conducted using the software MEGA7 (Kumar et al., 2016). Sequences of experimentally validated chloromethanedegraders are written in bold. Sequences marked with a ${ }^{13} \mathrm{C}$ icon result from DNA-SIP $\left({ }^{13} \mathrm{CH}_{3} \mathrm{Cl}\right)$ studies in soil microcosms from a deciduous German forest dominated by beech (16S RNA: LT674486.1 to LT674490.1; CmuA: LT674491.1 to LT674498.1 in Chaignaud et al. (2018)), clone libraries from Californian agricultural soils (16S RNA: AY439185.1 to AY439194.1; CmuA: AY439202 to AY439204 in Miller et al. (2004)), and CmuA from clone libraries from English woodland soil (AY934428 to AY934484) (Borodina et al., 2005). (A) 16S rRNA tree based on 197 nucleotide sequences. Thermotoga maritima sequence served as outgroup. (B) CmuA tree based on 60 amino acid sequences. Oceanicola batsensis HTCC2597 and Pelagibaca bermudensis HTCC2601 sequences served as outgroup. Pink triangles indicate sequences retrieved from metagenome JGI database. Condensed branch of 11 sequences in cluster 1 (uncultured bacterium clone Warwickshire enrichment 3 (AY934432), 25 (AY934433), 36 (AY934430) and 42 (AY934428); Uncultured bacterium clone Warwickshire garden soil 37 (AY934481); Uncultured bacterium clone Gibbet Hill soil 9 (AY934448), 16 (AY934452), and 37 (AY93448); Uncultured bacterium clone Tocil Wood soil 17 (AY934484), 25 (AY934444), and 38 (AY934439)). Condensed branch of 4 marine sediment metagenome sequences in cluster 2 (GAF77597.1, GAF84365.1, GAG35382.1, GAG79179.1 and GAI71391.1).

ecosystems, which are highly active sinks (Borodina et al., 2005; Chaignaud et al., 2018). In the laboratory, high chloromethane ratios (in the percent range) have been used to isolate and grow pure chloromethane-degrading cultures that originated from soil (Schäfer et al., 2007) in order to obtain enough biomass for growth and chloromethane degradation studies. The identification of natural microbial populations actively assimilating carbon from chloromethane was first achieved using stable isotope probing (DNA SIP) (Miller et al., 2004). Studies in soil revealed that bacterial population members of soil microbial communities take up carbon from amended chloromethane (Miller et al., 2004; Borodina et al., 2005; Chaignaud et al., 2017). Moreover, it has been demonstrated that methanotrophs, as investigated with a pure culture of Methylomicrobium album BG8, can assimilate carbon from chloromethane when a surplus of methanol occurs, although chloromethane alone was not assimilated (Han and Semrau, 2000). These findings suggest a possible co-metabolic lifestyle of some methanotrophs regarding chloromethane degradation. In a forest soil, the rate of chloromethane degradation was recently shown to be enhanced when methanol was present (Chaignaud et al., 2018). In this study, Beijerinckiceae (i.e. phylotypes affiliating closely with Methylovirgula ligni), assimilated carbon from methanol or from chloromethane as suggested by SIP experiments of soil microcosms amended with labelled or unlabelled methanol, chloromethane or both simultaneously (Chaignaud et al., 2017; Morawe et al., 2017).
Methylotrophic co-utilization of chloromethane with other $\mathrm{C}_{1}$ compounds such as methanol, which is found in larger amounts in the environment and utilized by most methylotrophs, may thus represent an important component of chloromethane sink activity. The utilization of methanol as an alternate substrate to chloromethane may favour the persistence of chloromethane-degrading populations in the context of shortage of chloromethane in natural habitats. The presence of pollutants such as toluene in ocean water was found to inhibit chloromethane and bromomethane uptake, thereby challenging the persistence of methyl halide-degrading populations and subsequent methyl halide oceanic uptake, which would in turn disturb an important component of the biogeochemical cycle of these ozone-depleting compounds (Goodwin et al., 2005).

\section{Future trends}

\section{Low- and high-affinity degraders}

One of the key aspects of future explorations of the methylotrophic chloromethane sink is the need to unravel the enzymes and pathways that define the global sink of halocarbons not only in bacteria but also in fungi. Future research needs to grasp the diversity of chloromethane-degrading-associated metabolisms and taxa associated with the microbial chloromethane sink. Much effort has focused on molecular processes for methylotrophic growth under laboratory conditions. Owing to technical 
limitations, so far biological chloromethane sinks have been assessed using higher than natural concentrations. Future investigations should focus on environmentally relevant chloromethane levels (picomolar). High variations in chloromethane flux emissions have been reported (Jaeger et al., 2018) so it can be postulated that low and high affinity chloromethane-degrading populations may be found in the environment, as for methane (Maxfield et al., 2009).

\section{Unknowns of the chloromethane cycle}

How plant chloromethane emissions vary during their developmental stage or their physiological states (chloride stress, pathogen invasion, exposure to chlorinated pesticides), and the role of chloromethane production by plants, is unknown (Bringel and Couée, 2018). Host-associated microbiota may elicit a response that modulates the interactive interplay between host/microbial cells/insects as found for other plant-produced VOCs (review by Bringel and Couée, 2015). For example, chloromethane regenerates veratryl alcohol during degradation of lignin by some white-rot fungi (Harper et al., 1990), and one may speculate that associated bacterial communities may interfere with this process. Similarly, methylotroph populations may interfere with chlorine output through volatilization via chloromethane emissions, as white-rot fungi and higher plants methylate chloride (Oberg, 2002).

On the bacterial side, even with $M$. extorquens strain $\mathrm{CM} 4$, in the in-labo best-characterized chloromethane degrader, our current understanding is not sufficient to predict its behaviour under environmental conditions. Key actors remain uncharacterized: the regulator of the $c m u$ pathway, the chemical nature of the native corrinoid cofactor of the CmuA methyltransferase from chloromethane to $\mathrm{H}_{4} \mathrm{~F}$, many genes involved in corrinoid cofactor metabolism (Roselli et al., 2013), and conserved genes adjacent to $c m u A$ such as cmuC (Fig. 8.4) (Michener et al., 2016). In fact, all the details of the dehalogenation reactions and carbon funnelling to central metabolism remain to be investigated physiologically, biochemically on wild-type and mutants. Unfortunately, reverse genetics for site-directed mutagenesis has not been successful so far in M. extorquens strain CM4
(Michener et al., 2016) and Hyphomicrobium sp. Nonetheless, complementary 'omics' technologies such metabolomics, fluxomics and experimental evolution are available for Methylorubrum studies (Ochsner et al., 2015).

\section{Biomarkers of chloromethane sinks}

Gene $c m u A$ is the only known biomarker for bacterial chloromethane utilization. It is rarely found in metagenomes (Table 8.2) (Jaeger et al., 2018a,b), and is absent in the genome of some chloromethane utilizers (Buddruhs et al., 2013) (Table 8.1). Together, these observations reveal the need to define $c m u A$-independent biomarkers of the chloromethane microbial sinks. In open oceans (Goodwin et al., 2005) and soils (Rasche et al., 1991; Chaignaud et al., 2018), co-substrate consumption may be a major driver of chloromethane microbial sinks. Thus, new strategies should be explored for investigating microbial $\mathrm{cmu}$-independent chloromethane-degrading pathways, such as experiments on co-consumption of chloromethane with mixtures of other environmentally relevant carbon sources, co-cultures of mixed populations (Nai and Meyer, 2018), and cultivation-independent approaches using single-cell labelling and identification, such as microfluidic cell sorting combined with 'omics' methods and Raman-FISH (Musat et al., 2012; Hol and Dekker, 2014). This quest for new biomarkers will help explore the dynamics and diversity of chloromethane-degrading microorganisms active in situ in natural and anthropogenic environments.

\section{Web resources}

\section{Data reporting on production and consumption of ozone depleting substances}

The Montreal Protocol on Substances that Deplete the Ozone Layer:

http://ozone.unep.org/en/treaties-and-decisions/ montreal-protocol-substances-deplete-ozone-layer Scientific Assessments of Ozone Depletion conducted under the auspices of the World Meteorological Organization (WMO) and the United Nations Environment Programme (UNEP): https://www.esrl.noaa.gov/csd/assessments/ ozone/and http://www.wmo.int/pages/prog/ arep/gaw/ozone/ 


\section{Genome of chloromethane-degrading}

\section{strains}

http://www.genoscope.cns.fr/agc/microscope opens the MicroScope platform that hosts $M$. extorquens CM4 genome and provides annotation results relative to BLAST similarities, COG assignations, enzymatic function prediction (PRIAM software), TMHMM and SignalP predictions, and synteny conservation (Syntonizer software). Complete Hyphomicrobium sp. MC1 and Vibrio orientalis CIP 102891 genomes available at https:// www.ncbi.nlm.nih.gov/nuccore/FQ859181 (Vuilleumier et al., 2011) and (http://www.ebi.ac.uk/ ena/data/view/Project:40487) (Yang et al., 1983), respectively. Comparative RNA-Seq data of $M$. extorquens CM4 grown with chloromethane or with methanol available at: https://www.genoscope.cns. $\mathrm{fr} / \mathrm{agc} / \mathrm{microscope} /$ transcriptomic/NGSProjectRNAseq.php?projType $=$ RNAseq

\section{References}

Amato, P., Demeer, F., Melaouhi, A., Fontanella, S., MartinBiesse, A.S., Sancelme, M., Laj, P., and Delort, A.M. (2007). A fate for organic acids, formaldehyde and methanol in cloud water: their biotransformation by micro-organisms. Atmos. Chem. Phys. 7, 4159-4169. https://doi.org/10.5194/acp-7-4159-2007

Amato, P., Brisebois, E., Draghi, M., Duchaine, C., FröhlichNowoisky, J., Huffman, J.A., Mainelis, G., Robine, E., and Thibaudon, M. (2017a). Main biological aerosols, specificities, abundance, and diversity. In Microbiology of Aerosols, A.M. Delort, and P. Amato, eds. (John Wiley \& Sons, Inc., Hoboken, NJ), pp. 1-21.

Amato, P., Joly, M., Besaury, L., Oudart, A., Taib, N., Moné, A.I., Deguillaume, L., Delort, A.M., and Debroas, D. (2017b). Active microorganisms thrive among extremely diverse communities in cloud water. PLOS ONE 12, e0182869. https://doi.org/10.1371/journal. pone.0182869

Attieh, J.M., Hanson, A.D., and Saini, H.S. (1995). Purification and characterization of a novel methyltransferase responsible for biosynthesis of halomethanes and methanethiol in Brassica oleracea. J. Biol. Chem. 270, 9250-9257. https://doi.org/10.1074/ jbc. 270.16 .9250

Biemann, K., Oro, J., Toulmin, P., Orgel, L.E., Nier, A.O., Anderson, D.M., Simmonds, P.G., Flory, D., Diaz, A.V., Rushneck, D.R., et al. (1976). Search for organic and volatile inorganic compounds in two surface samples from the chryse planitia region of Mars. Science 194, 72-76. https://doi.org/10.1126/science.194.4260.72

Bodelier, P.L., Meima-Franke, M., Hordijk, C.A., Steenbergh, A.K., Hefting, M.M., Bodrossy, L., von Bergen, M., and Seifert, J. (2013). Microbial minorities modulate methane consumption through niche partitioning. ISME J. 7, 2214-2228. https://doi.org/10.1038/ ismej.2013.99
Borodina, E., Cox, M.J., McDonald, I.R., and Murrell, J.C. (2005). Use of DNA-stable isotope probing and functional gene probes to investigate the diversity of methyl chloride-utilizing bacteria in soil. Environ. Microbiol. 7, 1318-1328. https://doi.org/10.1111/ j.1462-5822.2005.00819.x

Bringel, F., and Couée, I. (2015). Pivotal roles of phyllosphere microorganisms at the interface between plant functioning and atmospheric trace gas dynamics. Front. Microbiol. 6, 486. https://doi.org/10.3389/ fmicb.2015.00486

Bringel, F., and Couée, I. (2018). Plant-pesticide interactions and the global chloromethane budget. Trends Plant Sci. 23, 95-99. https://doi.org/10.1016/j. tplants.2017.12.001

Buddruhs, N., Chertkov, O., Petersen, J., Fiebig, A., Chen, A., Pati, A., Ivanova, N., Lapidus, A., Goodwin, L.A., Chain, P., et al. (2013). Complete genome sequence of the marine methyl-halide oxidizing Leisingera methylohalidivorans type strain (DSM 14336(T)), a representative of the Roseobacter clade. Stand. Genomic Sci. 9, 128-141. https://doi.org/10.4056/sigs.4297965

Cao, J., Lai, Q. Yuan, J., and Shao, Z. (2015). Genomic and metabolic analysis of fluoranthene degradation pathway in Celeribacter indicus P73 ${ }^{\mathrm{T}}$. Sci. Rep. 5, 7741. https:// doi.org/10.1038/srep07741

Carpenter, L.J., Reimann, S., Burkholder, J.B., Clerbaux, C., Hall, B.D., Hossaini, R., Laube, J.C., and Yvon-Lewis, S.A. (2014). Update on Ozone-Depleting Substances (ODSs) and other gases of interest to the Montreal protocol. In Scientific Assessment of Ozone Depletion, Global Ozone Research and Monitoring Project Report, A. Engel, and S.A. Montzka, eds. (World Meteorological Organization (WMO), Geneva, Switzerland), pp. 21-125. http://hdl.handle.net/2268/175647

Chaignaud, P., Maucourt, B., Weiman, M., Alberti, A., Kolb, S., Cruveiller, S., Vuilleumier, S., and Bringel, F. (2017). Genomic and transcriptomic analysis of growthsupporting dehalogenation of chlorinated methanes in Methylobacterium. Front. Microbiol. 8, 1600. https:// doi.org/10.3389/fmicb.2017.01600

Chaignaud, P., Morawe, M., Besaury, L., Kröber, E., Vuilleumier, S., Bringel, F., and Kolb, S. (2018). Methanol consumption drives the bacterial chloromethane sink in a forest soil. ISME J. 12, 2681-2693. https://doi. org/10.1038/s41396-018-0228-4

Chen, G., Kleindienst, S., Griffiths, D.R., Mack, E.E., Seger, E.S., and Löffler, F.E. (2017). Mutualistic interaction between dichloromethane- and chloromethanedegrading bacteria in an anaerobic mixed culture. Environ. Microbiol. 19, 4784-4796. https://doi. org/10.1111/1462-2920.13945

Chistoserdova, L. (2011). Modularity of methylotrophy, revisited. Environ. Microbiol. 13, 2603-2622. https:// doi.org/10.1111/j.1462-2920.2011.02464.x

Coulter, C., Hamilton, J.T., and Harper, D.B. (1993). Evidence for the existence of independent chloromethane- and S-adenosylmethionine-utilizing systems for methylation in Phanerochaete chrysosporium. Appl. Environ. Microbiol. 59, 1461-1466.

Coulter, C., Hamilton, J.T., McRoberts, W.C., Kulakov, L., Larkin, M.J., and Harper, D.B. (1999). Halomethane:bisulfide/halide ion methyltransferase, 
an unusual corrinoid enzyme of environmental significance isolated from an aerobic methylotroph using chloromethane as the sole carbon source. Appl. Environ. Microbiol. 65, 4301-4312.

Cox, M.J., Schäfer, H., Nightingale, P.D., McDonald, I.R., and Murrell, J.C. (2012). Diversity of methyl halidedegrading microorganisms in oceanic and coastal waters. FEMS Microbiol. Lett. 334, 111-118. https://doi. org/10.1111/j.1574-6968.2012.02624.x

DasSarma, P., and DasSarma, S. (2018). Survival of microbes in Earth's stratosphere. Curr. Opin. Microbiol. 43, 24-30. https://doi.org/10.1016/j.mib.2017.11.002

Delort, A.-M., Vaïtilingom, M., Amato, P., Sancelme, M., Parazols, M., Mailhot, G., Laj, P., and Deguillaume, L. (2010). A short overview of the microbial population in clouds: potential roles in atmospheric chemistry and nucleation processes. Atmos. Res. 98, 249-260. https:// doi.org/10.1016/j.atmosres.2010.07.004

Derendorp, L., Wishkerman, A., Keppler, F., McRoberts, C., Holzinger, R., and Röckmann, T. (2012). Methyl chloride emissions from halophyte leaf litter: dependence on temperature and chloride content. Chemosphere 87, 483-489. https://doi.org/10.1016/j. chemosphere.2011.12.035

Doronina, N.V., Sokolov, A.P., and Trotsenko, Y.A. (1996). Isolation and initial characterization of aerobic chloromethane-utilizing bacteria. FEMS Microbiol. Lett. 142, 179-183. https://doi. org/10.1111/j.1574-6968.1996.tb08427.x

Elsner, M., Zwank, L., Hunkeler, D., and Schwarzenbach, R.P. (2005). A new concept linking observable stable isotope fractionation to transformation pathways of organic pollutants. Environ. Sci. Technol. 39, 68966916. https://doi.org/10.1021/es0504587

Farhan Ul Haque, M., Besaury, L., Nadalig, T., Bringel, F., Mutterer, J., Schaller, H., and Vuilleumier, S. (2017). Correlated production and consumption of chloromethane in the Arabidopsis thaliana phyllosphere. Sci. Rep. 7, 17589. https://doi.org/10.1038/s41598017-17421-y

Fayolle, E.C., Öberg, K.I., Jørgensen, J.K., Altwegg, K., Calcutt, H., Müller, H.S.P., Rubin, M., van der Wiel, M.H.D., Bjerkeli, P., Bourke, T.L., et al. (2017). Protostellar and cometary detections of organohalogens. Nat. Astronomy 1, 703-708. https://doi.org/10.1038/ s41550-017-0237-7

Freedman, D.L., Swamy, M., Bell, N.C., and Verce, M.F. (2004). Biodegradation of chloromethane by Pseudomonas aeruginosa strain NB1 under nitratereducing and aerobic conditions. Appl. Environ. Microbiol. 70, 4629-4634. https://doi.org/10.1128/ AEM.70.8.4629-4634.2004

Gasc, C., and Peyret, P. (2018). Hybridization capture reveals microbial diversity missed using current profiling methods. Microbiome 6, 61. https://doi.org/10.1186/ s40168-018-0442-3

Gasc, C., Peyretaillade, E., and Peyret, P. (2016). Sequence capture by hybridization to explore modern and ancient genomic diversity in model and nonmodel organisms. Nucleic Acids Res. 44, 4504-4518. https://doi. org/10.1093/nar/gkw309

Gifford, S.M., Becker, J.W., Sosa, O.A., Repeta, D.J., and DeLong, E.F. (2016). Quantitative transcriptomics reveals the growth- and nutrient-dependent response of a streamlined marine methylotroph to methanol and naturally occurring dissolved organic matter. MBio 7, e01279-16. https://doi.org/10.1128/mBio.01279-16

Giovannoni, S.J., Hayakawa, D.H., Tripp, H.J., Stingl, U., Givan, S.A., Cho, J.C., Oh, H.M., Kitner, J.B., Vergin, K.L., and Rappé, M.S. (2008). The small genome of an abundant coastal ocean methylotroph. Environ. Microbiol. 10, 1771-1782. https://doi.org/10.1111/ j.1462-2920.2008.01598.x

Goodwin, K.D., Tokarczyk, R., Stephens, F.C., and Saltzman, E.S. (2005). Description of toluene inhibition of methyl bromide biodegradation in seawater and isolation of a marine toluene oxidizer that degrades methyl bromide. Appl. Environ. Microbiol. 71, 3495-3503. https://doi. org/10.1128/AEM.71.7.3495-3503.2005

Green, P.N., and Ardley, J.K. (2018). Review of the genus Methylobacterium and closely related organisms: a proposal that some Methylobacterium species be reclassified into a new genus, Methylorubrum gen. nov. Int. J. Syst. Evol. Microbiol. 68, 2727-2748. https://doi. org/10.1099/ijsem.0.002856

Halsey, K.H., Carter, A.E., and Giovannoni, S.J. (2012). Synergistic metabolism of a broad range of $\mathrm{Cl}$ compounds in the marine methylotrophic bacterium HTCC2181. Environ. Microbiol. 14, 630-640. https:// doi.org/10.1111/j.1462-2920.2011.02605.x

Hamilton, J.T., McRoberts, W.C., Keppler, F., Kalin, R.M., and Harper, D.B. (2003). Chloride methylation by plant pectin: an efficient environmentally significant process. Science 301, 206-209. https://doi.org/10.1126/ science. 1085036

Han, J.I., and Semrau, J.D. (2000). Chloromethane stimulates growth of Methylomicrobium album BG8 on methanol. FEMS Microbiol. Lett. 187, 77-81. https:// doi.org/10.1111/j.1574-6968.2000.tb09140.x

Hancock, T.L., Costello, A.M., Lidstrom, M.E., and Oremland, R.S. (1998). Strain IMB-1, a novel bacterium for the removal of methyl bromide in fumigated agricultural soils. Appl. Environ. Microbiol. 64, 28992905.

Harper, D.B. (2000). The global chloromethane cycle: biosynthesis, biodegradation and metabolic role. Nat. Prod. Rep. 17, 337-348.

Harper, D.B., and Hamilton, J.T.G. (2003). The global cycles of the naturally-occurring monohalomethanes. In Natural Production of Organohalogen Compounds, G. Gribble, ed. (Springer, Berlin, Heidelberg), pp. 17-41.

Harper, D.B., Buswell, J.A., Kennedy, J.T., and Hamilton, J.T. (1990). Chloromethane, methyl donor in veratryl alcohol biosynthesis in Phanerochaete chrysosporium and other lignin-degrading fungi. Appl. Environ. Microbiol. 56, 3450-3457.

Hartmans, S., Schmuckle, A., Cook, A.M., and Leisinger, T. (1986). Methyl chloride: naturally occurring toxicant and C-1 growth substrate. Microbiology 132, 11391142. https://doi.org/10.1099/00221287-132-4-1139

Heikes, B.G., Chang, W., Pilson, M.E.Q. Swift, E., Singh, H.B., Guenther, A., Jacob, D.J., Field, B.D., Fall, R., Riemer, D., et al. (2002). Atmospheric methanol budget and ocean implication. Global Biogeochem. Cycles 16, 80-1-80-13. https://doi.org/10.1029/2002GB001895 
Hol, F.J., and Dekker, C. (2014). Zooming in to see the bigger picture: microfluidic and nanofabrication tools to study bacteria. Science 346, 1251821. https://doi. org/10.1126/science.1251821

Itoh, N., Toda, H., Matsuda, M., Negishi, T., Taniguchi, T., and Ohsawa, N. (2009). Involvement of S-adenosylmethionine-dependent halide/thiol methyltransferase (HTMT) in methyl halide emissions from agricultural plants: isolation and characterization of an HTMT-coding gene from Raphanus sativus (daikon radish). BMC Plant Biol. 9, 116. https://doi. org/10.1186/1471-2229-9-116

Jaeger, N., Besaury, L., Kröber, E., Delort, A.M., Greule, M., Lenhart, K., Nadalig, T., Vuilleumier, S., Amato, P., Kolb, S., et al. (2018a). Chloromethane degradation in soils: a combined microbial and two-dimensional stable isotope approach. J. Environ. Qual. 47, 254-262. https://doi. org/10.2134/jeq2017.09.0358

Jaeger, N., Besaury, L., Röhling, A.N., Koch, F., Delort, A.M., Gasc, C., Greule, M., Kolb, S., Nadalig, T., Peyret, P., et al. (2018b). Chloromethane formation and degradation in the fern phyllosphere. Sci. Total Environ. 634, 12781287. https://doi.org/10.1016/j.scitotenv.2018.03.316

Jones, D.T., Taylor, W.R., and Thornton, J.M. (1992). The rapid generation of mutation data matrices from protein sequences. Comput. Appl. Biosci. 8, 275-282. https:// doi.org/10.1093/bioinformatics/8.3.275

Justicia-Leon, S.D., Ritalahti, K.M., Mack, E.E., and Löffler, F.E. (2012). Dichloromethane fermentation by a Dehalobacter sp. in an enrichment culture derived from pristine river sediment. Appl. Environ. Microbiol. 78, 1288-1291. https://doi.org/10.1128/AEM.07325-11

Keppler, F., Eiden, R., Niedan, V., Pracht, J., and Schöler, H.F. (2000). Halocarbons produced by natural oxidation processes during degradation of organic matter. Nature 403, 298-301. https://doi.org/10.1038/35002055

Keppler, F., Harper, D.B., Röckmann, T., Moore, R.M., and Hamilton, J.T.G. (2005). New insight into the atmospheric chloromethane budget gained using stable carbon isotope ratios. Atmos. Chem. Phys. 5, 24032411. https://doi.org/10.5194/acp-5-2403-2005

Keppler, F., Harper, D.B., Greule, M., Ott, U., Sattler, T., Schöler, H.F., and Hamilton, J.T. (2014). Chloromethane release from carbonaceous meteorite affords new insight into Mars lander findings. Sci. Rep. 4, 7010. https://doi. org/10.1038/srep07010

Kislyuk, A.O., Haegeman, B., Bergman, N.H., and Weitz, J.S. (2011). Genomic fluidity: an integrative view of gene diversity within microbial populations. BMC Genomics 12, 32. https://doi.org/10.1186/1471-2164-12-32

Kits, K.D., Kalyuzhnaya, M.G., Klotz, M.G., Jetten, M.S., Op den Camp, H.J., Vuilleumier, S., Bringel, F., Dispirito, A.A., Murrell, J.C., Bruce, D., et al. (2013). Genome sequence of the obligate gammaproteobacterial methanotroph Methylomicrobium album strain BG8. Genome Announc. 1, e0017013. https://doi. org/10.1128/genomeA.00170-13

Kleindienst, S., Higgins, S.A., Tsementzi, D., Chen, G., Konstantinidis, K.T., Mack, E.E., and Löffler, F.E. (2017). 'Candidatus Dichloromethanomonas elyunquensis' gen. nov., sp. nov., a dichloromethane-degrading anaerobe of the Peptococcaceae family. Syst. Appl. Microbiol. 40, 150159. https://doi.org/10.1016/j.syapm.2016.12.001
Kumar, S., Stecher, G., and Tamura, K. (2016). MEGA7: Molecular evolutionary genetics analysis version 7.0 for bigger datasets. Mol. Biol. Evol. 33, 1870-1874. https:// doi.org/10.1093/molbev/msw054

Lai, Q. Cao, J., Yuan, J., Li, F., and Shao, Z. (2014). Celeribacter indicus sp. nov., a polycyclic aromatic hydrocarbon-degrading bacterium from deep-sea sediment and reclassification of Huaishuia halophila as Celeribacter halophilus comb. nov. I. J. Syst. Evol. Microbiol. 64, 4160-4167. https://doi.org/10.1099/ ijs.0.069039-0

Leisinger, T., and Braus-Stromeyer, S.A. (1995). Bacterial growth with chlorinated methanes. Environ. Health Perspect. 103 (Suppl. 5), 33-36. https://doi. org/10.1289/ehp.95103s433

Li, S., Park, M.-K., Jo, C.O., and Park, S. (2017). Emission estimates of methyl chloride from industrial sources in China based on high frequency atmospheric observations. J. Atmos. Chem. 74, 227-243. https://doi. org/10.1007/s10874-016-9354-4

Manley, S.L. (2002). Phytogenesis of halomethanes: A product of selection or a metabolic accident? Biogeochemistry 60, 163-180. https://doi. org/10.1023/A:1019859922489

Marx, C.J., Bringel, F., Chistoserdova, L., Moulin, L., Farhan Ul Haque, M., Fleischman, D.E., Gruffaz, C., Jourand, P., Knief, C., Lee, M.C., et al. (2012). Complete genome sequences of six strains of the genus Methylobacterium. J. Bacteriol. 194, 4746-4748. https://doi.org/10.1128/ JB.01009-12

Maxfield, P.J., Hornibrook, E.R., and Evershed, R.P. (2009). Substantial high-affinity methanotroph populations in Andisols effect high rates of atmospheric methane oxidation. Environ. Microbiol. Rep. 1, 450-456. https:// doi.org/10.1111/j.1758-2229.2009.00071.x

McAnulla, C., McDonald, I.R., and Murrell, J.C. (2001a). Methyl chloride utilising bacteria are ubiquitous in the natural environment. FEMS Microbiol. Lett. 201, 151-155. https://doi.org/10.1111/j.1574-6968.2001. tb10749.x

McAnulla, C., Woodall, C.A., McDonald, I.R., Studer, A., Vuilleumier, S., Leisinger, T., and Murrell, J.C. (2001b). Chloromethane utilization gene cluster from Hyphomicrobium chloromethanicum strain $\mathrm{CM} 2^{\mathrm{T}}$ and development of functional gene probes to detect halomethane-degrading bacteria. Appl. Environ. Microbiol. 67, 307-316. https://doi.org/10.1128/ AEM.67.1.307-316.2001

McDonald, I.R., Warner, K.L., McAnulla, C., Woodall, C.A., Oremland, R.S., and Murrell, J.C. (2002). A review of bacterial methyl halide degradation: biochemistry, genetics and molecular ecology. Environ. Microbiol. 4, 193-203. https://doi.org/10.1046/ j.1462-2920.2002.00290.x

McRoberts, W.C., Keppler, F., Harper, D.B., and Hamilton, J.T.G. (2015). Seasonal changes in chlorine and methoxyl content of leaves of deciduous trees and their impact on release of chloromethane and methanol at elevated temperatures. Environ. Chem. 12, 426-437. https://doi.org/10.1071/EN14208

Meßmer, M., Wohlfarth, G., and Diekert, G. (1993). Methyl chloride metabolism of the strictly anaerobic, methyl chloride-utilizing homoacetogen strain MC. Arch. 
Microbiol. 160, 383-387. https://doi.org/10.1007/ BF00252225

Meßmer, M., Reinhardt, S., Wohlfarth, G., and Diekert, G. (1996). Studies on methyl chloride dehalogenase and O-demethylase in cell extracts of the homoacetogen strain MC based on a newly developed coupled enzyme assay. Arch. Microbiol. 165, 18-25. https://doi. org/10.1007/s002030050291

Michener, J.K., Camargo Neves, A.A., Vuilleumier, S., Bringel, F., and Marx, C.J. (2014a). Effective use of a horizontally-transferred pathway for dichloromethane catabolism requires post-transfer refinement. Elife 3. https://doi.org/10.7554/eLife.04279

Michener, J.K., Vuilleumier, S., Bringel, F., and Marx, C.J. (2014b). Phylogeny poorly predicts the utility of a challenging horizontally transferred gene in Methylobacterium strains. J. Bacteriol. 196, 2101-2107. https://doi.org/10.1128/JB.00034-14

Michener, J.K., Vuilleumier, S., Bringel, F., and Marx, C.J. (2016). Transfer of a catabolic pathway for chloromethane in Methylobacterium strains highlights different limitations for growth with chloromethane or with dichloromethane. Front. Microbiol. 7, 1116. https://doi.org/10.3389/fmicb.2016.01116

Miller, L.G., Kalin, R.M., McCauley, S.E., Hamilton, J.T., Harper, D.B., Millet, D.B., Oremland, R.S., and Goldstein, A.H. (2001). Large carbon isotope fractionation associated with oxidation of methyl halides by methylotrophic bacteria. Proc. Natl. Acad. Sci. U.S.A. 98, 5833-5837. https://doi.org/10.1073/ pnas. 101129798

Miller, L.G., Warner, K.L., Baesman, S.M., Oremland, R.S., McDonald, I.R., Radajewski, S., and Murrell,J.C. (2004). Degradation of methyl bromide and methyl chloride in soil microcosms: Use of stable $\mathrm{C}$ isotope fractionation and stable isotope probing to identify reactions and the responsible microorganisms. Geoch. Cosmoch. Acta 68, 3271-3283. https://doi.org/10.1016/j. gca.2003.11.028

Ming, D.W., Archer, P.D., Glavin, D.P., Eigenbrode, J.L., Franz, H.B., Sutter, B., Brunner, A.E., Stern, J.C., Freissinet, C., McAdam, A.C., et al. (2014). Volatile and organic compositions of sedimentary rocks in Yellowknife Bay, Gale crater, Mars. Science 343, 1245267. https://doi.org/10.1126/science. 1245267

Morawe, M., Hoeke, H., Wissenbach, D.K., Lentendu, G., Wubet, T., Kröber, E., and Kolb, S. (2017). Acidotolerant bacteria and fungi as a sink of methanol-derived carbon in a deciduous forest soil. Front. Microbiol. 8, 1361. https://doi.org/10.3389/fmicb.2017.01361

Musat, N., Foster, R., Vagner, T., Adam, B., and Kuypers, M.M. (2012). Detecting metabolic activities in single cells, with emphasis on nanoSIMS. FEMS Microbiol. Rev. 36, 486-511. https://doi.org/10.1111/j.15746976.2011.00303.x

Nadalig, T., Farhan UI Haque, M., Roselli, S., Schaller, H., Bringel, F., and Vuilleumier, S. (2011). Detection and isolation of chloromethane-degrading bacteria from the Arabidopsis thaliana phyllosphere, and characterization of chloromethane utilization genes. FEMS Microbiol. Ecol. 77, 438-448. https://doi.org/10.1111/j.15746941.2011.01125.x

Nadalig, T., Greule, M., Bringel, F., Vuilleumier, S., and Keppler, F. (2013). Hydrogen and carbon isotope fractionation during degradation of chloromethane by methylotrophic bacteria. MicrobiologyOpen 2, 893-900. https://doi.org/10.1002/mbo3.124

Nadalig, T., Greule, M., Bringel, F., Keppler, F., and Vuilleumier, S. (2014). Probing the diversity of chloromethane-degrading bacteria by comparative genomics and isotopic fractionation. Front. Microbiol. 5, 523. https://doi.org/10.3389/fmicb.2014.00523

Nagatoshi, Y., and Nakamura, T. (2009). Arabidopsis HARMLESS TO OZONE LAYER protein methylates a glucosinolate breakdown product and functions in resistance to Pseudomonas syringae pv. maculicola. J. Biol. Chem. 284, 19301-19309. https://doi.org/10.1074/ jbc.M109.001032

Nai, C., and Meyer, V. (2018). From axenic to mixed cultures: technological advances accelerating a paradigm shift in microbiology. Trends Microbiol. 26, 538-554 https://doi.org/10.1016/j.tim.2017.11.004.

Neufeld, J.D., Boden, R., Moussard, H., Schäfer, H., and Murrell, J.C. (2008). Substrate-specific clades of active marine methylotrophs associated with a phytoplankton bloom in a temperate coastal environment. Appl. Environ. Microbiol. 74, 7321-7328. https://doi. org/10.1128/AEM.01266-08

Nijenhuis, I., and Richnow, H.H. (2016). Stable isotope fractionation concepts for characterizing biotransformation of organohalides. Curr. Opin. Biotechnol. 41, 108-113. https://doi.org/10.1016/j. copbio.2016.06.002

Oberg, G. (2002). The natural chlorine cycle - fitting the scattered pieces. Appl. Microbiol. Biotechnol. 58, 565-581. https://doi.org/10.1007/s00253-001-0895-2

Ochsner, A.M., Sonntag, F., Buchhaupt, M., Schrader, J., and Vorholt, J.A. (2015). Methylobacterium extorquens: methylotrophy and biotechnological applications. Appl. Microbiol. Biotechnol. 99, 517-534. https://doi. org/10.1007/s00253-014-6240-3

Ohsawa, N., Tsujita, M., Morikawa, S., and Itoh, N. (2001). Purification and characterization of a monohalomethane-producing enzyme S-adenosylL-methionine: halide ion methyltransferase from a marine microalga, Pavlova pinguis. Biosci. Biotechnol. Biochem. 65, 2397-2404. https://doi.org/10.1271/ bbb.65.2397

Parisot, N., Peyretaillade, E., Dugat-Bony, E., Denonfoux, J., Mahul, A., and Peyret, P. (2016). Probe design strategies for oligonucleotide microarrays. Methods Mol. Biol. 1368, 67-82. https://doi.org/10.1007/978-1-49393136-1 6

Rasche, M.E., Hyman, M.R., and Arp, D.J. (1991). Factors limiting aliphatic chlorocarbon degradation by Nitrosomonas europaea: cometabolic inactivation of ammonia monooxygenase and substrate specificity. Appl. Environ. Microbiol. 57, 2986-2994.

Rhew, R.C., Østergaard, L., Saltzman, E.S., and Yanofsky, M.F. (2003). Genetic control of methyl halide production in Arabidopsis. Curr. Biol. 13, 1809-1813. https://doi.org/10.1016/j.cub.2003.09.055

Ribière, C., Beugnot, R., Parisot, N., Gasc, C., Defois, C., Denonfoux, J., Boucher, D., Peyretaillade, E., and Peyret, P. (2016). Targeted gene capture by hybridization to illuminate ecosystem functioning. Methods Mol. Biol. 1399, 167-182. https://doi.org/10.1007/978-1-49393369-3_10 
Roselli, S., Nadalig, T., Vuilleumier, S., and Bringel, F. (2013). The $380 \mathrm{~kb}$ pCMU01 plasmid encodes chloromethane utilization genes and redundant genes for vitamin B12- and tetrahydrofolate-dependent chloromethane metabolism in Methylobacterium extorquens CM4: a proteomic and bioinformatics study. PLOS ONE 8, e56598. https://doi.org/10.1371/ journal.pone.0056598

Sailaukhanuly, Y., Sárossy, Z., Carlsen, L., and Egsgaard, H. (2014). Mechanistic aspects of the nucleophilic substitution of pectin. On the formation of chloromethane. Chemosphere 111, 575-579. https:// doi.org/10.1016/j.chemosphere.2014.05.001

Šantl-Temkiv, T., Finster, K., Hansen, B.M., Pašić, L., and Karlson, U.G. (2013). Viable methanotrophic bacteria enriched from air and rain can oxidize methane at cloudlike conditions. Aerobiologia 29, 373-384. https://doi. org/10.1007/s10453-013-9287-1

Šantl-Temkiv, T., Amato, P., Gosewinkel, U., Thyrhaug, R., Charton, A., Chicot, B., Finster, K., Bratbak, G., and Löndahl, J. (2017). High-flow-rate impinger for the study of concentration, viability, metabolic activity, and ice-nucleation activity of airborne bacteria. Environ. Sci. Technol. 51, 11224-11234. https://doi.org/10.1021/ acs.est. $7 \mathrm{~b} 01480$

Schaefer, J.K., Goodwin, K.D., McDonald, I.R., Murrell, J.C., and Oremland, R.S. (2002). Leisingera methylohalidivorans gen. nov., sp. nov., a marine methylotroph that grows on methyl bromide. I. J. Syst. Evol. Microbiol. 52, 851-859. https://doi. org/10.1099/00207713-52-3-851

Schäfer, H., McDonald, I.R., Nightingale, P.D., and Murrell, J.C. (2005). Evidence for the presence of a CmuA methyltransferase pathway in novel marine methyl halide-oxidizing bacteria. Environ. Microbiol. 7, 839-852. https://doi.org/10.1111/ j.1462-2920.2005.00757.x

Schäfer, H., Miller, L.G., Oremland, R.S., and Murrell, J.C. (2007). Bacterial cycling of methyl halides. Adv. Appl. Microbiol. 61, 307-346. https://doi.org/10.1016/ S0065-2164(06)61009-5

Schulze-Makuch, D., Wagner, D., Kounaves, S.P., Mangelsdorf, K., Devine, K.G., de Vera, J.P., SchmittKopplin, P., Grossart, H.P., Parro, V., Kaupenjohann, M., et al. (2018). Transitory microbial habitat in the hyperarid Atacama Desert. Proc. Natl. Acad. Sci. U.S.A. 115, 2670-2675. https://doi.org/10.1073/ pnas. 1714341115

Studer, A., Vuilleumier, S., and Leisinger, T. (1999). Properties of the methylcobalamin: $\mathrm{H}_{4}$ folate methyltransferase involved in chloromethane utilization by Methylobacterium sp. strain CM4. Eur. J. Biochem. 264, 242-249.

Studer, A., Stupperich, E., Vuilleumier, S., and Leisinger, T. (2001). Chloromethane: tetrahydrofolate methyl transfer by two proteins from Methylobacterium chloromethanicum strain CM4. Eur. J. Biochem. 268, 2931-2938. https://doi.org/10.1046/j.14321327.2001.02182.x

Studer, A., McAnulla, C., Büchele, R., Leisinger, T., and Vuilleumier, S. (2002). Chloromethane-induced genes define a third C1 utilization pathway in Methylobacterium chloromethanicum CM4. J. Bacteriol. 184, 3476-3484. https://doi.org/10.1128/JB.184.13.3476-3484.2002

Toda, H., and Itoh, N. (2011). Isolation and characterization of a gene encoding a S-adenosyl-1-methioninedependent halide/thiol methyltransferase (HTMT) from the marine diatom Phaeodactylum tricornutum: Biogenic mechanism of $\mathrm{CH}_{3} \mathrm{I}$ emissions in oceans. Phytochem. 72, 337-343. https://doi.org/10.1016/j. phytochem.2010.12.003

Traunecker, J., Preuß, A., and Diekert, G. (1991). Isolation and characterization of a methyl chloride utilizing, strictly anaerobic bacterium. Arch. Microbiol. 156, 416-421. https://doi.org/10.1007/BF00248720

Vaïtilingom, M., Deguillaume, L., Vinatier, V., Sancelme, M., Amato, P., Chaumerliac, N., and Delort, A.M. (2013). Potential impact of microbial activity on the oxidant capacity and organic carbon budget in clouds. Proc. Natl. Acad. Sci. U.S.A. 110, 559-564. https://doi. org/10.1073/pnas.1205743110

Vannelli, T., Studer, A., Kertesz, M., and Leisinger, T. (1998). Chloromethane metabolism by Methylobacterium sp. strain CM4. Appl. Environ. Microbiol. 64, 1933-1936.

Vannelli, T., Messmer, M., Studer, A., Vuilleumier, S., and Leisinger, T. (1999). A corrinoid-dependent catabolic pathway for growth of a Methylobacterium strain with chloromethane. Proc. Natl. Acad. Sci. U.S.A. 96, 46154620. https://doi.org/10.1073/pnas.96.8.4615

Vorholt, J.A. (2012). Microbial life in the phyllosphere. Nat. Rev. Microbiol. 10, 828-840. https://doi.org/10.1038/ nrmicro2910

Vuilleumier, S., Nadalig, T., Ul Haque, M.F., Magdelenat, G., Lajus, A., Roselli, S., Muller, E.E., Gruffaz, C., Barbe, V., Médigue, C., et al. (2011). Complete genome sequence of the chloromethane-degrading Hyphomicrobium sp. strain MC1. J. Bacteriol. 193, 5035-5036. https://doi. org/10.1128/JB.05627-11

Wang, B., Tan, T., and Shao, Z. (2009). Roseovarius pacificus sp. nov., isolated from deep-sea sediment. Int. J. Syst. Evol. Microbiol. 59, 1116-1121. https://doi. org/10.1099/ijs.0.002477-0

Weigold, P., El-Hadidi, M., Ruecker, A., Huson, D.H., Scholten, T., Jochmann, M., Kappler, A., and Behrens, S. (2016). A metagenomic-based survey of microbial (de) halogenation potential in a German forest soil. Sci. Rep. 6, 28958. https://doi.org/10.1038/srep28958

Whitman, W.B., Coleman, D.C., and Wiebe, W.J. (1998). Prokaryotes: the unseen majority. Proc. Natl. Acad. Sci. U.S.A. 95, 6578-6583. https://doi.org/10.1073/ pnas.95.12.6578

Whittenbury, R., Phillips, K.C., and Wilkinson, J.F. (1970). Enrichment, isolation and some properties of methaneutilizing bacteria. J. Gen. Microbiol. 61, 205-218. https://doi.org/10.1099/00221287-61-2-205

Wuosmaa, A.M., and Hager, L.P. (1990). Methyl chloride transferase: a carbocation route for biosynthesis of halometabolites. Science 249, 160-162. https://doi. org/10.1126/science. 2371563

Yang, Y., Yeh, L.p., Cao, Y., Baumann, L., Baumann, P., Tang, J.S.-e., and Beaman, B. (1983). Characterization of marine luminous bacteria isolated off the coast of China and description of Vibrio orientalis sp. nov. Curr. Microbiol. 8, 95-100. https://doi.org/10.1007/ BF01566965 